\title{
El Primado romano en la Península Ibérica hasta el siglo X: Un análisis historiográfico*
}

\author{
Roman Papal Primacy in the Iberian Peninsula \\ until the Tenth Century. An Examination \\ of the Scholarship
}

Fernando Rodamilans Ramos**

\begin{abstract}
RESUMEN
La historiografía sobre la acción del Primado romano en la Península lbérica antes del siglo $X$ presenta notables divergencias interpretativas partiendo de un conjunto de fuentes relativamente escaso. En este trabajo se analizan los principales temas historiográfícos desarrollados en relación con esta materia, con el objeto de ofrecer el estado actual de las investigaciones.
\end{abstract}

\author{
PALABRAS CLAVE \\ Primado, primacía, Roma, Papado, \\ historiografía, Iglesia, España.
}

\section{ABSTRACT}

Based on a relatively small set of sources there are manifold divergent interpretations in the scholarship of the Roman Papal Primate's activity in the Iberian Peninsula prior to the tenth century. This study analyzes the main historiographical issues with the purpose of establishing the current status of research.

\section{KEY WORDS}

Primate, Primacy, Rome, Papacy, Scholarship, the Church, Spain.

\section{INTRODUCCIÓN}

En las últimas décadas se han ido publicando diferentes trabajos con el objetivo de llevar a cabo una puesta al día, o balance historiográfico, en torno al estado de la investigación sobre la Iglesia y el clero hispánicos en la Edad Media, al-

\footnotetext{
* Fecha de recepción del artículo: 2013-09-26. Fecha de aceptación del artículo: 2013-10-14.

** Departamento de Historia Medieval (UCM). C.e.: frodamilans@ucm.es
} 
gunos de carácter más general y otros limitando su análisis a una institución y su evaluación, o a un determinado periodo cronológico ${ }^{1}$.

Lo que se propone en las páginas siguientes es un recorrido historiográfico que desgrane los principales aspectos relacionados con las manifestaciones específicas del Primado en la Iglesia hispana, así como con la reacción suscitada en la misma frente a la acción de Roma. El objetivo es profundizar en los asuntos históricos concretos sobre los que se ha construido la historia de la primacía romana en España para alcanzar una visión suficiente que permita plasmar algunas conclusiones sobre el desarrollo historiográfico al respecto. A priori, la acción del Primado romano en la Península Ibérica tiene una importancia histórica suficiente como para dotarse de una cierta entidad historiográfica, ya que afecta directamente a la configuración de la Iglesia y, como se verá, a la interpretación de la misma. Presenta, no obstante, una primera dificultad específica, y es que se ha de abarcar un periodo que, historiográficamente, queda en buena parte a caballo entre el ámbito tardoantiguo y el altomedieval.

El límite cronológico superior establecido es el comienzo del llamado Siglo de Hierro del Papado. Por una parte, por la considerable parálisis que sufrió el conjunto de la acción exterior pontificia², incluyendo el ejercicio del Primado, tanto jurisdiccio-

\footnotetext{
1 Valgan como ejemplo los trabajos de LADERO QUESADA, Miguel Ángel, NIETO SORIA, José Manuel, «Iglesia y sociedad en los siglos XIII al XV (ámbito castellano-leonés). Estado de la investigación», En la España Medieval, Vol. 11 (1988), pp. 121-174; SANZ SANCHO, lluminado, «Para el estudio de la Iglesia medieval castellana», Estudios eclesiásticos, Vol. 73, Núm. 284 (1998), pp. 61-87; ARRANZ GUZMÁN, Ana, «Pedro I y el clero castellano en la historiografía contemporánea», Hispania, Vol. 50, Núm. 175 (1990), pp. 737-757; Ídem, «Las relaciones de Pedro I y el episcopado castellano en los episcopologios e historias locales de los siglos XVI-XIX», Poder y sociedad en la Baja Edad Media hispánica: estudios en homenaje al profesor Luis Vicente Díaz Martín, Vol. 1, Valladolid, 2002, pp. 27-36; DÍAZ IBÁÑEZ, Jorge, «El pontificado y los reinos peninsulares durante la Edad Media. Balance historiográfico», En la España medieval, Vol. 24 (2001), pp. 465-536. Éste es un estudio directamente relacionado con el tema del presente artículo, si bien abarca un marco cronológico y temático mucho más amplio. El Prof. Díaz comienza con un estudio de carácter general sobre la gestación de los estudios del Pontificado en España, así como de la paulatina edición de las fuentes más relevantes; MENA RAMíREZ, Néstor, Historia de la Historiografía eclesiástica española en el siglo XX, Tesis Doctoral, Universidad de Navarra, Pamplona, 2002; LOP OTÍN, María José, «Las catedrales y los cabildos catedralicios de la Corona de Castilla durante la Edad Media: un balance historiográfico», En la España Medieval, Vol. 26 (2003), pp. 371-404; Ídem, «La investigación sobre la Iglesia medieval toledana: balance y perspectivas», Medievalismo, Núm. 15 (2005), pp. 93-138; CÁRCEL ORTÍ, M. Milagros, «El clero secular en Europa en la Baja Edad Media. Bibliografía», Anuario de Estudios Medievales, Núm. 35/2 (2005), pp. 971-1.047; COELHO, María Helena da Cruz, «O que se vem investigando en História da Igreja Edad Media Portugal Edad Media tempos medievais», Medievalismo, Núm. 16 (2006), pp. 205-223; GARCÍA HERNÁN, Enrique, «Visión acerca del estado actual en España de la Historia de la Iglesia», Anuario de Historia de la Iglesia, Núm. 16 (2007), pp. 281-308; MUNSURI ROSADO, M. Nieves, «Clero e Iglesia en la Baja Edad Media Hispánica: estado de la cuestión», eHumanista, Núm. 10 (2008), pp. 133-169; VILAR, Hermínia Vasconcelos, "Estructuras e protagonistas religiosos na historiografia medieval portuguesa», Lusitania Sacra, 2 $2^{\text {a }}$ Série, Vol. XXI (2009), pp. 125-151; VIGIL MONTES, Néstor, «Las últimas aportaciones a la historia de los cabildos catedralicios en Castilla y Portugal en la Edad Media (2000-2010)", Studium Ovetense, Vol. XXXVIII (2010), pp. 103-133.

2 A pesar de ello encontramos algunas excepciones a dicha «parálisis», como por ejemplo, la notable actividad exterior del Papa Juan X (914-928), acción militar personal contra los sarracenos en Italia, acción evangelizadora en Croacia, situando la nueva sede metropolitana de Split bajo la jurisdicción de
} 
nal como doctrinal; pero, por otra parte, porque el pontificado de Nicolás I (858-867) marcó un punto de inflexión en la manifestación efectiva de la primacía pontificia, renovada con vigor por los obispos de Roma durante la Prerreforma gregoriana. No en balde Halphen ha denominado la época de Nicolás I como «la hora del Papado» ${ }^{3}$

El presente trabajo ha sido estructurado en cinco apartados: el primero de ellos pretende servir como punto de partida para el estudio de la institución analizada, y los cuatro siguientes se presentan en orden cronológico, teniendo en cuenta que las cesuras marcadas dependen en unos casos de la acción de la Sede romana, y en otros de la situación político-eclesiástica de la Península.

Se ha considerado oportuno comenzar con un sucinto repaso de las principales obras de producción nacional que, sin tratar específicamente de la cuestión del Primado, son un depósito de fuentes manejadas por los historiadores posteriores, así como una referencia de la problemática histórica de partida. En primer lugar, cabe hablar de los trabajos de edición de fuentes, los cuales aportan tanto las valiosas transcripciones de las mismas como, en algunos casos, una valoración crítica. Además de las magnas colecciones de Baronio, Belarmino, Mansi, Migne, Bail, los hermanos Ballerini, Jaffé, Duchesne o Ewald-Hartmann, resalta la importancia de las ediciones de fuentes realizadas en España desde el s. XVI: Juan Bautista Pérez concluyó en 1575 su Concilia Hispaniensia impressa, collata cum vetustis codicibus manuscriptis, por encargo del obispo de Cuenca e inquisidor general Gaspar Quiroga como parte de la magna obra de recopilación conciliar ordenada por Gregorio XIII; la obra de Juan B. Pérez quedó inédita pero está parcialmente presente en la recopilación de Sáenz de Aguirre, Collectio maxima Conciliorum omnium Hispaniae et Novi Orbis, de la que interesan para el presente ámbito de estudio los tres primeros volúmenes (Roma, 1693-1694). García de Loaisa, por su parte, publicó en Madrid en 1593 su Collectio Conciliorum Hispaniae. Nicolás Antonio, además de una revisión de la historiografía de los cronicones, es autor de una Bibliotheca Hispana Vetus, publicada por el mencionado cardenal Sáenz de Aguirre en 1696. De la producción del siglo XIX cabe destacar la edición crítica bilingüe de Juan Tejada y Ramiro, Colección de cánones y de todos los concilios de la Iglesia Española, en particular los dos primeros volúmenes (1849-1851). Entre las obras recientes revisten gran interés la edición y traducción de la obra conciliar hispana anterior a la invasión musulmana de José Vives, Concilios visigóticos e hispano-romanos (Madrid-Barcelona, 1963), así como la notable edición crítica de la Collectio Hispana, iniciada en 1966 por Gonzalo Martínez Díez y a la que se ha incorporado Félix Rodríguez, con un especial aprovechamiento para nuestro caso de los volúmenes IV-VI (1984-2002).

Roma, y acción legatina en Italia, Alemania, Francia, Dalmacia y Bulgaria. Otros casos fueron la carta a los obispos de Dalmacia de León VI (928), el nombramiento como legado apostólico en Alemania de Federico de Maguncia por León VII (936-939), el espaldarazo a Cluny de Juan XI (931-935) o la acción evangelizadora de Hungría y Polonia de Juan XIII (965-972).

3 HALPHEN, Carlomagno y el Imperio carolingio, Madrid, 1992 (1947). 
Asimismo, las grandes historias de España como la Coronica General del cronista de Castilla Ambrosio de Morales (1574-1586) - continuando con un renovado enfoque científico la de Florián de Ocampo- proporcionan abundante información sobre la historia de la Iglesia de España. Lugar especial merece la España Sagrada de Enrique Flórez (1747-1775), tanto como recopilación documental, como por su inmenso bagaje de interpretación crítica de la historia eclesiástica. Su obra fue continuada hasta 1957 sucesivamente por Manuel Risco, Antolín Merino, Pedro Sainz de Baranda, Vicente de la Fuente, Carlos Ramón Fort, Eduardo Jusué y Ángel C. Vega. Vicente de la Fuente escribió también su Historia eclesiástica de España (Barcelona, 1855-1859), iniciada a modo de adiciones a la obra del alemán Alzog y de la España Sagrada, y de la que interesa el primer tomo. Obra ésta completada y mejorada por la Historia Eclesiástica de España (1929-1936) de Zacarías García Villada, la cual, aunque truncada por la trágica muerte de su autor, alcanza todo el periodo aquí considerado.

\section{LA INSTITUCIÓN DEL PRIMADO DE ROMA}

Al estudiar la Iglesia de los primeros siglos se corre un cierto riesgo, a caballo entre el anacronismo y el presentismo, que merece la pena tomar en consideración. Las estructuras básicas de la Iglesia se han mantenido hasta nuestros días, tales como el episcopado, la organización de la geografía eclesiástica o la Sede romana. Pero las instituciones eclesiásticas han sufrido una notable transformación durante los últimos dos milenios, especialmente en lo que se refiere a las relaciones entre las distintas comunidades de cristianos, y particularmente a las relaciones de esas comunidades diversas con la Iglesia de Roma, que es el tema que atañe a este trabajo. Puesto que, además, el ámbito geográfico al que aquí se hace referencia es el de las iglesias españolas, conviene señalar que en este territorio los Pontífices ejercieron o pretendieron ejercer una función primacial, al igual que en el resto del orbe cristiano, pero también otra de tipo patriarcal. Sobre las implicaciones del primado y del patriarcado en la configuración de la Iglesia de los primeros siglos hay dos obras imprescindibles y consideradas ya clásicas. Se trata de las de José Madoz ${ }^{4}$ y Pierre Batiffol ${ }^{5}$. En la misma línea de Batiffol, G. Vries ${ }^{6}$ ha estudiado el tema específico de la posición de Roma frente a las Iglesias patriarcales del Oriente, mientras que Friedrich $\mathrm{Kempf}^{7}$ ha analizado en su conjunto el desarrollo del Primado tomando como punto de vista la constitución de las iglesias territoriales en los reinos germánicos del Occidente hasta el s. VIII.

${ }^{4}$ El Primado romano, Madrid, 1936.

${ }^{5}$ Cathedra Petri. Études d'Histoire ancienne de l'Église, París, 1938.

6 «La S. Sede ed i patriarcati cattolici d'Oriente», Orientalia Christiana Periódica, Vol. 27, Roma, 1961, pp. 313-361, en especial las pp. 313-326.

7 "Chiese territoriali e chiesa romana del secolo VIII», en I problemi dell'Occidente nel secolo VIII. XX Settimane di Studio del Centro Italiano di Studi sull'Alto Medioevo, Spoleto, 1973, Vol. I, pp. 293-317. 
Todas las cuestiones relativas al papel del Papa en la Iglesia, incluyendo de manera específica la revisión histórica de la doctrina del Primado romano, cobraron un renovado interés historiográfico en los años en torno a la celebración del Concilio Vaticano II. La inconclusa cuestión ecuménica ${ }^{8}$ y el desarrollo de un modelo de mayor colegialidad de la Iglesia romana fueron las razones principales que impulsaron una cierta producción historiográfica sobre el Primado, ya que éste guarda una inevitable relación con ambos asuntos. En torno a la colegialidad salieron a la luz varias obras de gran interés, puesto que analizaban los orígenes del Primado y el papel del episcopado en relación con la autoridad pontificia ${ }^{9}$; coinciden en identificar la posición del obispo de Roma desde los comienzos de la Iglesia como centro necesario de la comunión católica, y como símbolo de la unidad del colegio episcopal, que reconoce su potentiorem principalitatem ${ }^{10}$. Por su parte, la obra de Manuel Sotomayor es la que mejor refleja la recepción de esta temática en la historiografía española ${ }^{11}$.

Los trabajos anteriormente señalados identifican una génesis muy temprana de la primacía pontificia, de naturaleza petrina y base patrística, pero también se ha desarrollado un modelo de interpretación crítica que niega la existencia durante los tres primeros siglos del Primado romano, el cual habría sido una suerte de solución histórica sobrevenida. Este modelo tiene su origen y su mayor acogida en el ámbito de la historiografía protestante, pero se desarrolla a instancias de la vía abierta por los trabajos sobre el ecumenismo y la colegialidad en Vaticano II $^{12}$.

8 A pesar de ello, se produjo un notable avance con la aprobación del Decretum De Oecumenismo
(Unitatis redintegratio). Yves Congar (†1995), uno de sus artífices y sobresaliente ecumenista católico
del momento, ha sido un especialista en la cuestión del episcopado y el Primado. Sobre los cuatro de-
cretos relacionados con el ecumenismo, vid. VV.AA., Vaticano II. El único Pueblo de Dios, Madrid, 1968.
9 MACCARRONE, Michele, «La dottrina del Primato papale», en Le Chiese nei regni dell'Europa
occidentale e i loro rapporti con Roma sino all'800. VII Settimane di Studio del Centro Italiano di Studi
sull'Alto Medioevo, Spoleto, 1960, Vol. II, pp. 633-742; HERTLING, L., Communio, chiesa e papato
nell'antichitá cristiana, Roma, 1961; RAHNER, Karl, S. I., RATZINGER, Joseph, Episcopado y primado.
Questiones disputatae 11, Barcelona, 1965 (1961); VOGEL, C., Unidad de la Iglesia y pluralidad de for-
mas históricas de organización eclesiástica desde el siglo III al V, en CONGAR, Y. M.-J., DUPUY, B. D.
(Dirs.), El episcopado y la Iglesia universal, Barcelona, 1966 (París, 1962), pp. 537-579; RAHNER, Karl,
S. I., Lo dinámico en la Iglesia, Barcelona, 1963; COLSON, Jean, L'épiscopat catholique. Collégialité et
primauté dans les trois premiers siècles de l'Église, París, 1963; LECUYER, J., Etudes sur la collégialité
épiscopale, Lyon, 1964; MAROT, H., «Descentralización estructural y Primado en la Iglesia antigua»,
Concilium, Núm. 7 (1965), pp. 16-33.

10 El obispo de Roma ha sido, desde sus comienzos, la cabeza y el centro de un colegio episcopal al que, sin embargo, no sustituye. Pero, al mismo tiempo, la doctrina del Primado no se limita a la cuestión colegial, sino que se identifica un poder propio e independiente de Pedro y sus sucesores. En ciertos momentos históricos, la defensa de posturas excluyentemente pro-colegiales (o conciliares) 0 pro-papalistas ha generado tensiones y conflictos, desde tiempos de San Cipriano hasta el Vaticano I.

${ }^{11}$ La Iglesia en la España romana y visigoda (siglos I-VIII), en GARCÍA VILLOSLADA, Ricardo (Dir.), Historia de la Iglesia en España, T. I, Madrid, 1979.

12 Destacan los trabajos de McCUE, James F., «The Roman Primacy in the Second Century and the problem of the Development of Dogma», Theological Studies, Núm. 25/2 (1964), pp. 161-196; EMPIE, Paul C., MURPHY, T. Austin (Eds.), Papal Primacy and the Universal Church. Lutheran and Catholics in Dialogue, 5, Minneapolis, 1974, obra principalmente teológica, pero con interés por los capítulos del mencionado McCue, «The Roman Primacy in the Patristic Era: The Beginnings Through Nicea», pp. 44-72, y de PIEPKORN, Arthur C., «The Roman Primacy», pp. 73-97. Un buen resumen de la cuestión 
Uno de los temas más relevantes en esta línea de investigación es el origen de la successio petrina, discutido en profundidad a raíz de un estudio de Oscar Cullmann ${ }^{13}$ que cuestionaba tanto la realidad histórica como la validez teológica de tal sucesión apostólica.

En la obra de Karl Baus ${ }^{14}$ se planteó una visión bien matizada de una consolidación paulatina de la primacía de la Iglesia de Roma, paralela al desarrollo de la propia constitución eclesiástica y que habría alcanzado su plenitud durante el pontificado de León I (440-461) ${ }^{15}$. La historiografía suele considerar a este Papa como el artífice de la consolidación de una doctrina jurídico-teológica sobre la primacía pontificia, de ahí que casi todos los estudios sobre su pontificado traten en mayor o menor medida la cuestión del Primado. El trabajo más exhaustivo al respecto es el de Walter Ullman ${ }^{16}$, que además incluye una abundante bibliografía, especialmente de origen alemán. Arthur S. McGrade ${ }^{17}$ ofrece una útil interpretación complementaria al considerar que se produjo un cambio de rumbo hacia una concepción papalista de la primacía pontificia, coincidiendo con el final del Imperio de Occidente y manifestada sobre todo en Gelasio I, frente a la concepción más ecuménica de León Magno. La doctrina gelasiana también es considerada por Ottorino Bertolini ${ }^{18}$ como punto de partida del desarrollo del poder temporal del Papado, poder que se consolidó en el s. VIII afectando irremediablemente a la concepción del Primado. El autor analiza la construcción de este dominio temporal hasta Adriano I. J. Oroz Reta ${ }^{19}$ insiste en que el deber pontificio de la sollicitudo

del Primado romano desde el planteamiento del ecumenismo, en The Lutheran-Catholic Dialogue In The United States, «Differing Attitudes Toward Papal Primacy», s/l, 1973, disponible en la página web de la Conferencia Episcopal de EE. UU., United States Conference of Catholic Bishops, www.usccb.org

13 Petrus. Jünger-Apostel-Märtyrer, Zürich, 1952. Cullmann admite el liderazgo inicial de Pedro (Mt 16, 18-19), pero considera que sólo se mantuvo durante el comienzo de su labor apostólica, reduciéndose al final de su vida y, en cualquier caso, sin posibilidad de sucesión. Esta tesis fue acogida favorablemente por algunos autores del ámbito protestante, como LOWE, J., Saint Peter, Oxford, 1957, y también por parte de algunos ecumenistas católicos, sobre todo por el controvertido KARRER, Otto, Peter and the Church. An examination on Cullmann's thesis, Friburgo, 1963. Por el contrario, autores como PORÚBCAN, S., «The Consciousness of Peter's Primacy in the New Testament», Archivum Historiae Pontificiae, Núm. 5 (1967), pp. 9-39, han tachado de arbitraria la interpretación histórico-bíblica de Cullmann. La obra de DALLA COSTA, Giovanni Battista, Concezione del Primado papale nelle lettere dei Romani Pontefici della prima metà del V secolo, Roma, 1966, diferencia entre la continuidad cierta e ininterrumpida de la idea del Primado romano, que radica en la revelación, y el ejercicio externo del Primado, que se fue desarrollando hasta alcanzar un punto de inflexión en el s. V.

14 «El afianzamiento de la constitución eclesiástica durante el siglo III», en JEDIN, Hubert (Dir.), Historia de la Iglesia, Tomo I, Barcelona, 1980 (Friburgo, 1962), pp. 494-521.

15 BAUS, Karl, EWIG, Eugen, «Evolución del Primado romano desde Milcíades a León I», ibídem, pp. 33-369.

16 «Leo I and the Theme of Papal Primacy», Journal of Theological Studies, Num. 11 (1960), pp. 25-51.

17 «Two Fifth-Century Conceptions of Papal Primacy» en BOWSKY, William M. (Ed.), Studies in Medieval and Renaissance History, Vol. VII, Lincoln, 1970, pp. 3-45.

18 «Le origini del poder temporale e del dominio temporale dei papi», en I problemi dell'Occidente nel secolo VIII. XX Settimane di Studio del Centro Italiano di Studi sull'Alto Medioevo, Spoleto, 1973, Vol. I, pp. 231-255.

19 «San León Magno, Papa de la Romanidad», Helmantica, Núm. 13 (1962), pp. 163-191. El autor relaciona la consolidación del Primado con la cesión del testigo de la Roma imperial a la Roma espiritual, en la persona de León I. 
omnium ecclesiarum se manifestó de forma ejemplar en la acción doctrinal y jurisdiccional del Papa León, para quien los demás obispos comparten la misión de la cura pastoralis, pero no tienen la plenitud del poder, que es del obispo de Roma. En tiempos más recientes, Josep Vilella Masana ${ }^{20}$ ha estudiado las relaciones entre las primitivas iglesias locales, introduciendo con ello la cuestión de la búsqueda de la unidad de la Iglesia a través de la communio con Roma.

Es destacable, por último, el simposio dirigido por Michele Maccarrone ${ }^{21}$, presidente de la Comisión Pontifica de Ciencia Histórica, celebrado por encargo del entonces Prefecto de la Congregación para la Doctrina de la Fe, Cardenal Joseph Ratzinger. Con la intención de realizar una renovación teológica sobre el Primado del obispo de Roma, se decidió comenzar por una revisión histórica, que incidió sobre las principales temáticas historiográficas: el mandato petrino, la sucesión apostólica y la successio primacial, las tres zonas de la potestas papal (según la tesis de Batiffol), la evolución del episcopado en los primeros siglos, el Primado y la communio, y la colegialidad de la Sede romana.

Los trabajos recogidos en este primer apartado permiten contextualizar, desde un punto de vista más eclesiológico, los hechos referidos específicamente a las relaciones de la Iglesia española con el Papado, las cuales además aparecen estudiadas en distinto grado en estas obras, como parte de la problemática más amplia del Primado romano.

\section{RELACIONES ENTRE LA PENÍNSULA IBÉRICA Y EL PAPADO ANTES DEL AÑO 526}

Los principales hitos de las relaciones del Papado con la Hispania romana han sido tratados de manera general en los trabajos de José Orlandis ${ }^{22}$, Ángel C. Vega $^{23}$ y Manuel Sotomayor ${ }^{24}$, con abundantes referencias a su vez tanto a las fuentes como a la bibliografía. Una forma alternativa de analizar las relaciones entre Roma y la Hispania antigua y visigoda ha sido llevada a cabo a través del análisis de la expansión del culto de los santos locales ${ }^{25}$.

20 «In alia plebe: cartas de comunión en las iglesias de la Antigüedad», en DELMAIRE, Roland, DESMULLIEZ, Janine, GATIER, Pierre-Louis (Eds.), Correspondances. Documents pour l'histoire de I'Antiquité tardive. Actes du colloque international, Lille, 20-22 novembre 2003, Lyon, 2009, pp. 83-113.

21 Il Primato del vescovo di Roma nel primo millennio. Ricerche e testimonianze. Atti del Symposium storico-teológico. Roma, 9-13 Ottobre 1989, Ciudad del Vaticano, 1991.

22 «El Primado romano en Hispania durante la Antigüedad Tardía», Historia, instituciones, documentos, Núm. 14 (1987), pp. 13-25.

23 «El Primado Romano en la Iglesia española desde sus orígenes hasta el siglo VII», Revista Española de Teología, Núm. 2 (1942), pp. 63-99.

24 Opus Cit.

25 GARCÍA RODRÍGUEZ, Carmen, El culto de los santos en la España romana y visigoda, Madrid, 1966, con útiles referencias a los episodios de contactos de algunos de los santos hispanos con el Pontificado, como el caso de Santo Toribio de Astorga. 


\subsection{Basilides y Marcial}

La primera intervención conocida del Pontificado Romano en los asuntos de la Iglesia hispana es el caso de la deposición de los obispos Basílides y Marcial, controvertido hasta el punto de que se ha llegado a cuestionar la realidad histórica de tal deposición ${ }^{26}$. La visión historiográfica de estos prelados ha basculado entre la plena exaltación de su catolicidad y la consideración de herejes libeláticos que realizara Menéndez Pelayo ${ }^{27}$. Quintana Prieto ${ }^{28}$ resume estas diversas posturas en un trabajo sobre el proceso de cristianización de Astorga que incluye el periodo de las persecuciones y apostasías como las de Basílides y Marcial. Ramón Teja ${ }^{29}$ facilita un breve resumen del recorrido historiográfico en torno a la autenticidad de este suceso, así como un estudio para encajar al clero involucrado en la primitiva organización eclesiástica hispana. De este mismo autor ${ }^{30}$ destaca un conciso y sumamente crítico análisis sobre la historiografía reciente de la Iglesia española de los primeros siglos, incluyendo como ejemplos el tratamiento de la cuestión de Basílides y Marcial y del priscilianismo, tema éste que se analizará en el siguiente apartado. En la misma línea, José Fernández Ubiña ${ }^{31}$ plantea las razones de la historiografía nacional y extranjera (católica y protestante) que han influido en una visión distorsionada o monolítica del Cristianismo de los primeros siglos en España.

Considerándola auténtica, la carta sinodal de San Cipriano no sólo es el documento más antiguo que proporciona noticias concretas sobre la Iglesia en Hispania, sino que se trata además de la primera apelación formal conocida ante la Santa Sede. Los obispos Basílides de León y Marcial de Mérida fueron acusados de libeláticos y depuestos en favor de los prelados Sabino y Félix (ca. 254), tal como explica Severino González Rivas ${ }^{32}$, señalando además las graves consecuencias canónicas de la apostasía y la penitencia pública.

${ }^{26}$ PÉREZ LLAMAZARES, Julio, «Basílides y Marcial, ¡Obispos venerables!...», en Ídem, Historia de la Real Colegiata de S. Isidoro, de León, León, 1927, pp. 309-319; GARCÍA DE LA FUENTE, A., «El caso del obispo Marcial de Mérida. Rehabilitación de una figura española del siglo III», Revista de Estudios Extremeños, 1933, pp. 105-153.

27 MENÉNDEZ PELAYO, Marcelino, Historia de los heterodoxos españoles, Libro 1, Cap. I/II, Madrid, 1880.

28 "La cristianización de Astorga», en Actas del I Congreso Internacional Astorga Romana, Astorga, 1986, T. I, pp. 91-121.

29 "Mérida cristiana en el siglo III: sus primeros obispos», en Mérida y Santa Eulalia. Actas de las Jornadas de Estudios Eulalienses. Noviembre 1993, Mérida, 1995, pp. 33-44.

30 «Una mirada a los estudios sobre el cristianismo antiguo en España», en SANTOS, Juan, TEJA, Ramón (Eds.), Revisiones de Historia Antigua III. El cristianismo. Aspectos históricos de su origen y difusión en Hispania. Actas del Symposium de Vitoria-Gasteiz (25 al 27 de noviembre de 1996), Vitoria, 2000, pp. 29-36.

31 «Los orígenes del cristianismo hispano: algunas claves sociológicas», Hispania Sacra, Vol. 59, Núm. 120 (2007), pp. 427-458; «Comunidades cristianas y jerarquía eclesiástica en la Hispania preconstantiniana», en ALVAR, J. (Ed.), Homenaje al Profesor J. M. Blázquez. Antigüedad: religiones y sociedades, Madrid 1998, vol. VI, pp. 55-77.

32 La penitencia en la primitiva iglesia española; estudio histórico, dogmático y canónico de la penitencia en la iglesia española, desde sus orígenes hasta los primeros tiempos de la invasión musulmana, Salamanca, 1949, pp. 27-40; QUINTANA PRIETO, Augusto, «Primeros siglos de cristianismo en el convento jurídico asturicense», Legio VII Gemina, León, 1970, pp. 443-474. 
La única fuente directa que se conserva sobre la apelación de los obispos hispanos es la carta 67 de San Cipriano de Cartago, que ha sido traducida por Zacarías García Villada ${ }^{33}$ y Julio Campos ${ }^{34}$, ambos con referencias al Primado romano. El Prof. Teja ${ }^{35}$ ha publicado un estudio que desgrana las principales cuestiones tanto históricas como historiográficas surgidas en torno a la carta sinodal, de las cuales las dos que aquí cobran especial relevancia son, por una parte, el reconocimiento efectivo de autoridad entre las Iglesias de Cartago y Roma y, por otra, la relación de ambas con la Iglesia hispana. El primero de los asuntos ha sido tratado desde un punto de vista eclesiológico por Adrien Demoustier ${ }^{36}$, identificando en la obra de San Cipriano una concepción de la catolicidad de la Iglesia que pasa inevitablemente por la unión a Roma. Jules Lebreton y Jacques Zeiller ${ }^{37}$ defienden que se produjo la consolidación de una autoridad preeminente de la Sede romana durante la época de Cipriano de Cartago, e incluyen un apartado de bibliografía adicional sobre el Primado. Óscar García ${ }^{38}$ matiza la anterior interpretación, pues considera que hubo una inicial negación teórica de la primacía romana, pero que dicha negación fue superada en la práctica por quienes acudieron a Roma en busca de legitimidad. En ese camino hacia la primacía, la autoridad jerárquica pontificia convivió con una autoridad moral como la de Cipriano. Esta tesis es la contraria de la que en su día presentó Charles E. Schrader ${ }^{39}$, quien, en un trabajo que analiza el desarrollo histórico del juramento episcopal como indicador del grado de evolución de la monarquía pontificia, señaló que la jurisdicción de Roma sobre los obispos del Occidente estuvo inicialmente mediatizada en la práctica, pero no así en la teoría.

Una de las claves interpretativas radica en identificar cuál fue la naturaleza de las relaciones entre la Iglesia en Hispania y en el Norte de África, ya que dicha naturaleza afectaría al reconocimiento del Primado romano en Hispania. Un exclusivo origen africano del Cristianismo hispano ha sido el principal argumento del Prof. Blázquez Martínez ${ }^{40}$ para negar rotundamente tal reconocimiento. Otros au-

${ }^{33}$ Historia Eclesiástica de España, T.l/1, Madrid, 1929, pp. 185 y ss.

34 Obras de San Cipriano. Edición bilingüe. Tratados. Cartas, Madrid, 1964.

35 «La carta 67 de S. Cipriano a las comunidades cristianas de León-Astorga y Mérida: algunos problemas y soluciones», en GONZÁLEZ BLANCO, Antonino, BLÁZQUEZ MARTINEZ, José M. (Eds.), Antigüedad y Cristianismo. VII. Cristianismo y aculturación en tiempos del Imperio romano, Murcia, 1990, pp. 115-124.

36 «Épiscopat et union à Rome selon Saint Cyprienen», Recherches de Science Religieuse, Núm. 52 (1964), pp. 337-369. Nótese que el P. Demoustier publicó este trabajo en pleno desarrollo del Vaticano II, en el que la doble cuestión de la singularidad y la universalidad de las iglesias fue un asunto largamente discutido.

37 «La Sede romana», en FLICHE, Agustín, MARTIN, Víctor (Dirs.), Historia de la Iglesia. Vol. II. La Iglesia en la penumbra, Valencia, 1976, pp. 539-560.

38 «Aportaciones exteriores al proceso de cristianización de Gallaecia: las relaciones con la Iglesia romana (ss. IV-VI)», Hispania Antiqua, Núm. 25 (2001), pp. 347-369.

39 «The Historical Development of the Papal Monarchy», Catholic Historical Review, Núm. 22 (1936), pp. 259-282.

40 «Posible origen africano del cristianismo español», Archivo Español de Arqueología 40, Núm. 115/116 (1967), pp. 30-50. 
tores como P. De Palol ${ }^{41}$ y Manuel Díaz y Díaz ${ }^{42}$ ya habían señalado la dependencia en origen de la Iglesia española respecto a las iglesias africanas, pero en sus trabajos no niegan el respeto a la primacía romana, sino que interpretan que fue aquella dependencia la que generó la costumbre de la apelación a Cartago. La continuidad de dicha costumbre ha sido defendida por M. Vallejo Girvés ${ }^{43}$ en el contexto de la influencia del Oriente en tierras hispanas. Manuel Sotomayor ${ }^{44}$, respondiendo al Prof. Blázquez, se ha posicionado a favor de una diversidad de influencias y un origen no exclusivamente africano del Cristianismo hispano, considerando que al menos puede afirmarse el ejercicio de una autoridad patriarcal -que no primacial- de Roma en Hispania. Un estudio de Luis Ángel García Moreno ${ }^{45}$ recoge los principales aspectos conflictivos en relación con los orígenes del Cristianismo en España.

En la misma línea de Blázquez, aunque desde un análisis estrictamente documental, Geoffrey Dunn ${ }^{46}$, especialista en San Cipriano, concluye que en tiempos del obispo cartaginense no existió reconocimiento de la primacía pontificia ni en África ni en España, ni tampoco intención de ejercer tal primacía por parte del obispo de Roma, al menos no en un sentido jurisdiccional. Sólo identifica una actitud deferente hacia Roma como sede apostólica principal del Occidente.

La reciente tesis doctoral de Ricard Salcedo Gómez ${ }^{47}$ analiza y amplia el corpus epistolar generalmente manejado de San Cipriano. Su trabajo permite estudiar la postura de la Iglesia de Cartago sobre los dos obispos hispanos poniéndola en relación con la cuestión más amplia y trascendente de los lapsi. A la luz de este modelo de análisis cobran renovado interés algunos estudios anteriores, como los de José Campmany ${ }^{48}$ y Giovanni Mongelli ${ }^{49}$, cuyas conclusiones son opuestas a las que se han mostrado hasta este momento. Campmany estudia la obra doctrinal de Cipriano y sitúa los sucesos referidos a Hispania como un episo-

\footnotetext{
41 «Algunos aspectos históricos y arqueológicos del Cristianismo en la Tarraconense y en las Galias», Caesaraugusta, Núm. VI (1956), pp. 141-167.

42 «En torno a los orígenes del Cristianismo hispánico», en GÓMEZ-TABANERA, José Manuel, Las raíces de España, Madrid, 1967, pp. 423-443.

43 «Influjo oriental en la Hispania del siglo V. A propósito de la consulta de Vital y Constancio a Capreolo de Cartago", Espacio, Tiempo y Forma. Serie II, Núm. 4 (1991), pp.351-358. Este trabajo estudia la consulta doctrinal de unos monjes hispanos al obispo Capreolo de Cartago en el s. V., concluyendo que en esta época la Iglesia hispana continuaba teniendo a la africana como referencia.

44 SOTOMAYOR, Manuel, «Influencia de la Iglesia de Cartago en las Iglesias Hispanas (A propósito de un artículo de J. Ma․ Blázquez», Gerión, Núm. 7 (1989), pp. 277-287.

45 «El cristianismo en las Españas: los orígenes», en SOTOMAYOR, M., FERNÁNDEZ UBIÑA, J., El concilio de Elvira y su tiempo, Granada, 2005, pp. 169-193.

46 Cyprian and the Bishops of Rome. Questions of Papal Primacy in the Early Church (Early Christian Studies, Vol. 11), Strathfield (Australia), 2007.

47 El «Corpus» epistolar de Cipriano de Cartago (249-258): estructura, composición y cronología, Universidad de Barcelona, 2007, disponible en Tesis Doctorales en Red, http://hdl.handle.net/10803/2600

48 «San Cipriano de Cartago, maestro y pastor en la persecución», Estudios Eclesiásticos, Vol. 33 , Núm. 130 (1959), pp. 275-302.

49 «La Chiesa di Cartagine contro Roma durante l'episcopato di S. Cipriano (249-258)», Miscellanea Francescana, T. LIX, Núm. I-II, Roma, 1959, pp. 104-201.
} 
dio más de su posición frente a los cismáticos y los lapsi, y en el contexto de su teología de la persecución. Añadiendo el factor de las tensas relaciones personales del obispo de Cartago con el Papa Esteban, su conclusión es que San Cipriano, defensor implacable de la unidad de la Iglesia, cuya expresión visible considera que es la Cathedra Petri, se encontró en un callejón sin salida al defender su doctrina. Mongelli realizó un amplio estudio sobre el conflicto entre Roma y Cartago en tiempos de Cipriano, analizando todos los hechos hasta llegar al punto culminante que fue la disputa bautismal. Considera seguro el reconocimiento de un Primado real del obispo de Roma por parte de Cipriano, aunque no exclusivo, sino como cabeza de un corpus episcopale. Su trabajo incluye un listado con la bibliografía esencial sobre Cipriano de Cartago.

Finalmente, cabe destacar por su importancia como especialista en el periodo a Victor C. De Clercq ${ }^{50}$, quien en su magna obra sobre el obispo Osio, y partiendo del estudio de la legislación conciliar de Elvira, Nicea y Sárdica, defiende la romanidad de la Iglesia hispana y el reconocimiento permanente de la máxima autoridad del obispo de Roma.

\subsection{Priscilianismo}

El tratamiento de esta herejía ha constituido uno de los principales ejes de la historiografía del s. IV, y está en mayor o menor medida como trasfondo de las relaciones del Pontificado con la Iglesia hispana hasta mediado el s. V. A continuación se desgranan las cuestiones historiográficas suscitadas a raíz de las actuaciones e intervenciones del Papado sobre el priscilianismo.

\section{Carta del Papa Siricio a Himerio de Tarragona (385)}

Se considera la primera - quizás segunda- decretal pontificia conservada ${ }^{51}$, y es el más antiguo registro epistolar existente entre el clero hispano y el obispo de Roma. Siricio contestó a la carta que el obispo Himerio de Tarragona había enviado al Papa Dámaso, en la que el hispano le detallaba la situación caótica del clero tras la condena llevada a cabo en el concilio de Zaragoza (380). El Papa respondió a Himerio encargándole ser el transmisor de las órdenes papales al resto del episcopado, lo cual recuerda a la actuación del Papa León I con respecto a Toribio de Astorga, como se verá más adelante. José María Fernández Catón ${ }^{52}$ ha analizado el contenido de la carta de Siricio en el marco de los movimientos ascéticos hispanorromanos, que es donde sitúa, al igual que José María Bláz-

50 Ossius of Cordova: a contribution to the history of the Constantinian period, Washington, 1954.

51 Sería la segunda decretal si se considerase como tal la carta del Papa Dámaso a los obispos de la Galia. Las cartas decretales eran en sí mismas una afirmación del Primado de Roma.

52 «Manifestaciones ascéticas en la Iglesia hispanorromana del siglo IV», Studium Legionense, Núm. 3, León, 1962, pp. 171-267. 
quez ${ }^{53}$, el priscilianismo; ambos han fijado su atención en las condenas del Concilio de Zaragoza, estudiado por José Orlandis y Domingo Ramos-Lissón ${ }^{54}$.

EI Prof. Vilella Masana ${ }^{55}$ también ha realizado un análisis exhaustivo de la decretal, que interpreta como una manifestación de la autoridad romana en Hispania. El mismo autor ${ }^{56}$ ha estudiado específicamente el proceso contra Prisciliano y explica, partiendo de las fuentes, cómo se produjo una actuación conjunta del Papa Siricio y del obispo Ambrosio de Milán para restablecer la unidad de la Iglesia por vía de la communio con Roma.

En relación con la actuación del Himerio, Teresa Sardella ${ }^{57}$ considera que el recurso del obispo hispano ante el Papa es una prueba del reconocimiento de la autoridad del Primado de Roma, planteando además una hipótesis más amplia sobre las motivaciones de Himerio y Siricio en relación con el priscilianismo.

Antes de celebrarse el I Concilio de Zaragoza, al parecer el Papa Dámaso fue consultado por los obispos hispanos, exponiéndoles que no se podía condenar a personas ausentes sin el debido proceso. El recién ordenado obispo de Ávila acudió en 382 a Roma junto con los prelados afines a su causa Instancio y Salviano para buscar el apoyo papal tras la reprobación del sínodo zaragozano. Ramón Hernánde ${ }^{58}$ ha realizado un repaso histórico-doctrinal de este movimiento priscilianista, incluyendo un listado bibliográfico desde 1889-1971, aunque atiende en menor medida la cuestión de las relaciones con Roma. Cabe destacar la narración clásica de los hechos acaecidos en torno al movimiento priscilianista realizada por Ramos Loscertales ${ }^{59}$, citada con frecuencia en obras posteriores.

Prisciliano instó al Papa Dámaso a que interviniera directamente en el asunto, o al menos a que ordenase convocar un concilio hispano, elevando para ello una apología - el Liber ad Damasum - a la gloria de la Sede Apostólica. Autores como Ángel Vega ${ }^{60} 0$, más recientemente, Óscar Núñez García ${ }^{61}$, no dudan de que Prisciliano estuvo convencido de la autoridad última de Roma en este pleito, e inscriben

53 «Priscilianismo, introductor del ascetismo en Gallaecia», en I Reunión Gallega de Estudios Clásicos (Santiago-Pontevedra, 2-4 julio 1979), Santiago de Compostela, 1981, pp. 210-236.

${ }^{54}$ ORLANDIS, José, RAMOS-LISSÓN, Domingo, Historia de los concilios de la España romana y visigoda, Pamplona, 1986.

55 «La Epístola 1 de Siricio: estudio prosopográfico de Himerio de Tarragona», Augustinianum, Vol. 44/2 (2004), pp. 337-369.

56 «Priscilianismo galaico y política antipriscilianista durante el siglo V», Antiquité Tardive, Núm. 5 (1997), pp. 177-185; «Un obispo-pastor de época teodosiana: Prisciliano», Studia Ephemeridis Augustinianum, Núm. 58/2 (1997), pp. 503-530.

57 «Papa Siricio e i movimenti ereticali nella Spagna di Teodosio l», en TEJA, Ramón, PÉREZ, Cesáreo (Eds.), Actas. Congreso Internacional La Hispania de Teodosio. 1997, Salamanca, 1998, pp. $247-254$.

58 «Prisciliano y el priscilianismo», en FLICHE, Agustín, MARTIN, Víctor (Dirs.), Historia de la Iglesia, Vol. IV, Valencia, 1976, pp. 637-658.

59 Prisciliano. Gesta Rerum, Salamanca, 1952.

60 «El Primado Romano...»

61 «Aportaciones exteriores al proceso de cristianización de Gallaecia: las relaciones con la Iglesia Romana (ss. IV-VI)», Hispania Antiqua, Núm. 25 (2001), pp. 347-370. 
estas apelaciones en un contexto de consolidación de la supremacía papal, con el precedente de los cánones de Sárdica. Por el contrario, la obra de Henry Chadwick $^{62}$, que se ha convertido en un clásico sobre el tema, plantea una hipótesis distinta, considerando que Prisciliano simplemente dijo al Papa Dámaso lo que estimaba necesario para lograr modificar su postura hacia el movimiento, lo mismo que hizo después con Ambrosio de Milán. En todo caso, esta interpretación de las intenciones de Prisciliano, al igual que los nulos resultados obtenidos de su visita a Roma, son compatibles con el reconocimiento efectivo que se dio a los cánones de Sárdica. Por otra parte, M. Victoria Escribano Paño ${ }^{63}$, especialista en el fenómeno priscilianista, minimiza el papel del pontificado en un asunto cuyos ritmos parecen marcados por los esfuerzos legitimadores del usurpador imperial Máximo ${ }^{64}$.

\section{Priscilianismo después de Prisciliano: actuaciones de Inocencio I y León Magno}

Pocos años después de la ejecución en Tréveris, la intervención del Papa Inocencio I (401-417) contra el priscilianismo a través de la Saepe me, en apoyo a las decisiones del I Concilio de Toledo (400), estuvo fundamentada en la autoridad doctrinal y jurisdiccional del Primado romano. Así lo han señalado G. B. Dalla Costa ${ }^{65}$, destacando el hecho de que la iniciativa fuera del Papa, y Fernando-J. de Lasala ${ }^{66}$, relacionando las intervenciones de Inocencio I en Hispania y Galia (priscilianismo) o África (pelagianismo) con la misión de cura pastoralis universal de la Iglesia de Roma. A. García Conde ${ }^{67}$ ha insistido en la integridad doctrinal del Primado de Roma como faro en medio de un Cristianismo asaltado en el siglo IV por las herejías y por las injerencias imperiales.

Ya en pleno s. V, la preocupación por las alteraciones del priscilianismo en el noroeste peninsular llevó al obispo Toribio de Astorga a enviar al diácono Pervinco a Roma portando tres documentos para el Papa León I: una epistola familiaris, un commonitorium sobre las doctrinas priscilianistas del momento y un libellus de refutación de las mismas. León I respondió con la epístola Quam laudabiter (441), con la que O. Núñez García ${ }^{68}$ considera que León Magno avanzó un paso más en el desarrollo del Primado, al imponerse como autoridad en materia de fe. En definitiva,

\footnotetext{
62 Prisciliano de Ávila, Madrid, 1977.

63 «Estado actual de los estudios sobre el Priscilianismo», en SANTOS, Juan, TEJA, Ramón (Eds.), Revisiones de Historia Antigua. III. El Cristianismo. Aspectos históricos de su origen y difusión en Hispania, Vitoria, 2000, pp. 263-287.

${ }^{64}$ Esta es la conclusión que se extrae del trabajo de OLIVARES GUILLEM, Andrés, «Actitud del Estado romano ante el Priscilianismo", Espacio, Tiempo y Forma. Serie II, Núm. 14 (2001), pp. 115-127.

65 Concezione del Primato papale... El autor considera la Saepe me como una manifestación de la Sollicitudo omnium ecclesiarum, expresión característica de la autoridad del Papa.

66 «Aportaciones al contexto histórico de la Iglesia católica de comienzos del siglo V. Las Historias de Osorio, la intervención de Inocencio I en la crisis priscilianista y el primer Concilio de Toledo (401)», Archivum Historiae Pontificae, Núm. 46 (2008), pp. 7-30. Dalla Costa, Concezione del Primato..., incluye dentro de esta sollicitudo pontificia su actuación en la lliria a través del vicario Anisio.

67 «En el Concilio I de Zaragoza ¿fueron condenados nominalmente los jefes priscilianistas? », Cuadernos de Estudios Gallegos, 1946, pp. 223-230.

68 Opus Cit.
} 
si en el caso de Basílides y Marcial el Primado romano se manifestó principalmente en su vertiente jurisdiccional, ahora lo hizo en su vertiente doctrinal ${ }^{69}$.

A. Quintana Prieto $^{70}$ ha estudiado la figura de Toribio y su relación con el Papa León, especialmente en cuanto a la determinación de la jurisdicción episcopal del hispano y de sus atribuciones. Su trabajo defiende la existencia de una estructura eclesiástica bien organizada desde tiempos de Basílides y no duda en considerar a Toribio como metropolitano de la provincia, incluyendo un episcopologio asturicense hasta el pontificado de su santo obispo. Sobre la figura de Toribio de Astorga contamos con la obra de Luis Alonso Luengo ${ }^{71}$, aunque parece mezclar lo histórico con lo hagiográfico. Más recientemente ha tratado el tema Lorenzo Martínez Ángel ${ }^{72}$, pero es en la tesis doctoral de Manuel Prieto Vilas ${ }^{73}$ donde aparecen mejor contextualizados los protagonistas de este conflicto hispano, así como las relaciones entre obispos y metropolitanos, y los modelos jurídico-administrativos tardoimperiales, asunto importante para comprender la naturaleza de las relaciones con la Santa Sede. Vilella Masana ${ }^{74}$, por su parte, ha realizado un recorrido prosopográfico por las iglesias hispanas del s. IV, con especial énfasis en todos los personajes relacionados con el priscilianismo.

En su conocido trabajo de interpretación socioeconómica del priscilianismo, Abilio Barbero ${ }^{75}$ planteó la hipótesis de que la carta de León I fuera una falsificación ${ }^{76}$, a raíz de la posible inconsistencia cronológica en las actas conservadas del I Concilio de Toledo, que mencionan al Papa León. Esta hipótesis había sido rebatida argumentando que en 447 se celebró por iniciativa del Pontífice un segundo concilio toledano, en el cual se habría confirmado el símbolo del 400 con una nueva redacción, que es la que ha llegado hasta nosotros. J. Ruíz-Goyo ${ }^{77}$, experto en la

${ }^{69}$ Lo cual corroboraría la línea historiográfica señalada en el primer epígrafe sobre León I y su desarrollo de la primacía.

70 «Primeros siglos de cristianismo en el convento jurídico asturicense», Legio VII Gemina, León, 1970, pp. 443-474.

71 Santo Toribio obispo de Astorga (Un momento de la formación de España), Madrid, 1939.

72 «Santo Toribio de Astorga en el declive del Imperio Romano», Estudios Humanísticos. Historia, Núm. 8 (2009), pp. 9-24.

${ }^{73}$ Los Obispos Hispanos a fines de Imperio Romano (ss. IV-VI). El nacimiento de una élite social, Universidad Complutense de Madrid, Madrid, 1994.

74 «Las iglesias y las cristiandades hispanas: panorama prosopográfico», en TEJA, Ramón (Ed.), La Hispania del siglo IV: administración, economía, sociedad, cristianización, Bari, 2002, pp. 117-159. Es destacable la labor de investigación y publicación realizada desde 1997 hasta la actualidad por el Grup de Recerques en Antiguitat Tardana (GRAT), bajo la dirección del Prof. Vilella Masana, de la Universidad de Barcelona. Puede accederse a buena parte de sus publicaciones en www.ub.edu/grat/grat01.htm

75 «El priscilianismo, ¿herejía o movimiento social?», Cuadernos de Historia de España, Núm. 37/38 (1963), pp. 5-41. No obstante, el propio A. Barbero parece aceptar en un estudio posterior la autenticidad de la carta: «Los síntomas españoles y la política religiosa de Carlomagno», En la España Medieval, Vol. 4 (1984), pp. 87-138. Estaríamos ante uno de los primeros escritos que contienen el Filioque, con las graves consecuencias históricas que se conocen sobre este asunto.

76 Hipótesis ya defendida en su día por KÜNSTLE, R., Antipriscilliana, Friburgo, 1905, especialmente las pp. 117-125.

77 «Carta dogmática de San León Magno a Santo Toribio, Obispo de Astorga», Estudios Eclesiásticos, Vol. 15, Núm. 59/3 (1936), pp. 367-379. 
obra de León I, analizó el contenido de la epístola de San León a Toribio de Astorga para concluir que en ella se fundamentó el célebre Libellus in modum symboli del obispo Pastor, también conocido como símbolo del I Toledano, aunque el autor considera que se trató del concilio celebrado por encargo del propio Papa León ${ }^{78}$. En esta línea coinciden M. Sotomayor ${ }^{79}$, J. Campos ${ }^{80}$-quien ha realizado un estudio crítico textual y lingüístico de la epístola-y J. A. De Aldama ${ }^{81}$ en su análisis exhaustivo de esta controversia y del símbolo antipriscilianista del Toledano I.

\subsection{Cartas del Papa Hilario. El conflicto del obispo Silvano}

El Papa Hilario (461-468), que había sido legatus de León I en el Latrocinio de Éfeso (449), también tuvo ocasión de intervenir en la vida de la Iglesia hispana, respondiendo a sendas cuestiones de los obispos de la Tarraconense sobre ciertas ordenaciones episcopales inválidas, por un lado, y sobre el posible traslado a la sede vacante de Barcelona del obispo de otra diócesis, por otro. Las consultas realizadas al Pontífice reflejan el respeto a la normativa de Sárdica sobre la jurisdicción y el Primado, tal como ha analizado de forma concluyente Urbano Espinosa Ruiz ${ }^{82}$, quien reconoce una preeminencia indiscutida del obispo de Roma. Koldo Larrañaga Elorza ${ }^{83}$ ofrecen una contextualización partiendo del primero de los asuntos, que puede completarse con el estudio que ha realizado María Victoria Escribano Paño ${ }^{84}$ de todas las comunicaciones epistolares relacionadas, prestando especial atención a la excusatio del obispo Silvano que un grupo de notables laicos de la Tarraconense presentó ante el Papa. El hecho en sí de que varios honorati y possesores locales de la zona del Medio y Alto Ebro se dirigieran a Roma para mediar en un asunto como éste, con independencia de sus motivaciones ${ }^{85}$, es indicativo de su concepción sobre la autoridad del obispo de Roma.

78 El mencionado símbolo tendría como fuentes las propias actas del I Toledano, la Fides Damasi de Baquiario y esta carta de León I a Toribio de Astorga. Nótese, además, que la Fides de Baquiario pudo haber sido escrita por este monje hispano en la propia Roma. Vid. RUíZ-GOYO, J., Opus Cit. Ello vendría a reforzar una imagen de autoridad doctrinal efectiva de la Sede Apostólica sobre la Iglesia hispana del s. V.

79 La Iglesia en la España...

80 «La epístola antipricilianista de S. León Magno», Helmantica, Núm. 13 (1962), pp. 269-308.

81 El Símbolo Toledano I. Su texto, su origen, su posición en la historia de los símbolos, Roma, 1934.

82 Calagurris Iulia, Logroño, 1984. El autor considera las consultas al Papa Hilario y su posterior intervención como una culminación del afianzamiento del Primado romano en Hispania, un proceso que se extendió sin solución de continuidad desde el caso de Basílides y Marcial.

83 «En torno al caso del obispo Silvano de Calagurris: consideraciones sobre el estado de la iglesia del alto y medio Ebro a fines del Imperio", Veleia: Revista de prehistoria, historia antigua, arqueología y filología clásicas, Núm. 6 (1989), pp. 171-192.

84 «La iglesia calagurritana entre ca. 457 y 465 . El caso del obispo Silvano», en Calahorra. Bimilenario de su fundación. Actas del I Symposium de Historia de Calahorra, s.I., 1984, pp. 265-272.

85 Las actuaciones de estos aristócratas en el caso de Silvano han sido interpretadas como un ejemplo más de la tensión entre el poder central visigodo y los poderes locales, en CASTELLANOS, Santiago, MARTÍN VISO, Iñaki, «The local articulation of central power in the north of the Iberian Peninsula (500-1000)», Early Medieval Europe, Núm. 13/1 (2005), pp. 1-42. 
Urbano Espinosa y García Moreno ${ }^{86}$ han considerado un contexto político extraeclesial más amplio en torno al caso de Silvano: por una parte, por la referida intervención de los honorati; por otra, porque la reactivación de la querella con la segunda carta de los obispos fue provocada por el dux Vicentius, personaje estudiado por ambos autores en el contexto de la crisis de autoridad imperial del s. V. En cuanto a la consulta sobre la sede de Barcelona, J. Vilella ${ }^{87}$ presenta un análisis de esta segunda intervención pontificia, así como de los demás hitos de las relaciones entre el episcopado hispano y el Papado desde el prisma del final del orden imperial en la Hispania del s. V.

En relación con las herramientas e instituciones que el Papado fue desarrollando para ejercitar su acción primacial, cabe señalar que Hilario envió sus dos cartas de respuesta con el subdiácono Trajano, una dirigida a todos los obispos de la Tarraconense y otra a su metropolitano Ascanio (465). La naturaleza del envío de Trajano lo sitúa en el límite que separa a un mero enviado o baiulus de un legado papal propiamente dicho ${ }^{88}$.

\subsection{Los vicariatos apostólicos}

Para comprender la naturaleza de los vicariatos apostólicos se ha considerado importante profundizar previamente en dos cuestiones esenciales de la historia de la organización eclesiástica. Por una parte, en la constitución metropolitana, que en Hispania comenzó a institucionalizarse en el s. IV. Una cuestión específica es la capitalidad política imperial de la diócesis hispana, que ha sido analizada por R. Étienne ${ }^{89}$. Demetrio Mansilla ${ }^{90}$ realizó los primeros estudios de conjunto sobre la génesis del modelo metropolitano hispano, que han sido renovados y ampliados con el trabajo de Vilella Masana ${ }^{91}$. Por su parte, Justo Fernández Alonso ${ }^{92}$ presenta una visión completa de conjunto sobre la organización de la Iglesia hispanovisigoda. Resulta especialmente útil para el estudio de las relaciones de poder de la

\footnotetext{
86 «Vincentius dux prouinciae Tarraconensis. Algunos problemas de la organización militar del Bajo Imperio en Hispania», Hispania Antiqua, VII (1977), pp. 79-89.

87 «La correspondencia entre los obispos hispanos y el papado durante el siglo V», Studia Ephemeridis Augustinianum, Núm. 46 (1994), pp. 458-465.

88 Como tal legado lo considera Úrbano Espinosa, Calagurris lulia...

89 «Mérida, capitale du vicariat des Espagnes», en Homenaje a Sáenz de Buruaga, Badajoz, 1982 pp. 201-208.

90 «Orígenes de la organización metropolitana en la Iglesia española», Hispania Sacra, Núm. 12 (1959), pp. 1-36; «Obispados y metrópolis del Occidente peninsular hasta el siglo X», Braccara Augusta, Núm. 22 (1968), pp. 11-40.

91 «Las primacías eclesiásticas en Hispania durante el siglo IV», Polis. Revista de formas e ideas políticas de la Antigüedad Clásica, Núm. 10 (1998), pp. 269-285.

92 «Organización del clero desde el punto de vista pastoral», en Ídem, La cura pastoral en la España romanovisigoda, Roma, 1955, pp. 191-254.
} 
Iglesia hispana del período visigodo la contextualización que Juan F. Rivera Recio $^{93}$ realizó sobre el origen metropolitano y primacial de la sede toledana.

Por otra parte, es importante el análisis de las bases que rigieron las relaciones jurisdiccionales y de primacía entre el Pontífice de Roma y el resto de los obispos del orbe, no sólo los metropolitas, para lo cual son útiles las obras señaladas en el apartado sobre la institución del Primado, y muy en especial la dirigida por Yves Congar y Bernard Dupuy ${ }^{94}$.

Para analizar los vicariatos apostólicos hispanos parece adecuado comenzar poniéndolos en relación con los dos vicariatos más conocidos y estudiados, Tesalónica y Arlés, pero sobre todo con este último, ya que la historia del vicariato apostólico de Tesalónica respondió a unas motivaciones políticas propias en relación con la pugna multisecular con el Imperio de Oriente por aquella región fronteriza de la lliria. García Moreno ${ }^{95}$ ha realizado un estudio sobre la situación política de las Galias y de Hispania en relación con el vicariato de Patroclo de Arlés, a partir de una de las fuentes más conocidas, la carta 11 de Constancio a San Agustín. De dicha fuente parece extraerse que la autoridad del arzobispo de Arlés era superior a la de los obispos de la Tarraconense, cuyas decisiones podrían apelarse ante aquél ${ }^{96}$.

Un tema especial es cómo la jurisdicción otorgada por los sucesivos Papas a sus vicarios apostólicos interfirió inevitablemente con la de los metropolitanos, como no podía ser de otra manera, pues los vicarios eran una herramienta de intervención pontificia en las iglesias locales o nacionales que se iban formando, como lo ha analizado Philip Grierson ${ }^{97}$ para el caso del vicariato de Arlés. No obstante, en los nombramientos vicariales los Pontífices limitaban expresamente las funciones del vicario dejando a salvo los derechos o privilegios de los metropolitanos. Una excepción fue la facultad que se otorgó a los vicarios de Tesalónica y de Arlés de autorizar las formatae litterae para los desplazamientos episcopales, una prerrogativa que era propia de los metropolitanos desde el Concilio de Elvira (c. 8). Ángel Riesco Terrero ${ }^{98}$ ha profundizado en la naturaleza jurídica de estas cartas,

\footnotetext{
93 «Encumbramiento de la Sede toledana durante la dominación visigótica», Hispania Sacra, Vol. 8, Núm. 15 (1955), pp. 3-34.

94 El episcopado y la Iglesia universal, Barcelona, 1966 (París, 1962).

95 «Nueva luz sobre la España de las invasiones de principios del siglo V. La epístola XI de Consencio a S. Agustín", en MERINO, Marcelo (Ed.), Verbo de Dios y palabras humanas. En el XVI centenario de la conversión cristiana de San Agustín, Pamplona, 1988, pp. 153-174.

96 Un repaso exhaustivo del contenido de la mencionada carta 11, que presenta especial interés por el análisis que ofrece sobre el proceso de las causas eclesiásticas y su relación con las causas civiles: KULIKOWSKI, Michael, «Fronto, the bishops, and the crowd: Episcopal justice and communal violence in fifth-century Tarraconensis», Early Medieval Europe, Núm. 11/4 (2002), pp. 295-320.

97 GRIERSON, Philip, «Rostagnus of Arles and the Pallium», The English Historical Review, Vol. XLIX, 193 (1934), pp. 74-83.

98 RIESCO TERRERO, Ángel, «Consideraciones en torno a la Diplomática Episcopal Antigua y Medieval (s. V-XIII)», en Homenaje al Profesor Juan Torres Fontes, Murcia, 1987, T. II, p. 1.347.
} 
una cuestión que afectaba a las provincias hispanas como subordinadas al vicariato de Arlés y que han estudiado Fernández Alonso ${ }^{99}$ y Vilella Masana ${ }^{100}$.

Para comprender las relaciones de dependencia de las iglesias hispanas respecto a la sede arelatense y el cambio que se produjo a raíz de los nombramientos de vicarios apostólicos, es recomendable acudir a los trabajos de Eberhard $\mathrm{F}$. Bruck $^{101}$, García Moreno ${ }^{102}$ y Vilella Masana ${ }^{103}$. Desde San Cesáreo, los arzobispos de Arlés tuvieron el título de legados o vicarios apostólicos en las Galias, pero el poder primacial efectivo de Arlés fue escaso y se extinguió poco después del pontificado de Gregorio I, como han analizado Pietro Conte ${ }^{104}$ y Michele Maccarrone ${ }^{105}$, este último con una visión todavía más restrictiva en cuanto al poder de la sede de Arlés.

Este periodo concreto del comienzo del s. VI presentó, además, unos condicionantes políticos que resultan insoslayables. En primer lugar, coincidió con el forzoso abandono de los visigodos de su Reino de Tolosa y el establecimiento definitivo en la Península Ibérica, época en la que Edward James ${ }^{106}$ ha considerado que los obispos hispanos y galos comenzaron a divergir. Por otra parte, es el tiempo del auge de los ostrogodos y de su proyección política hacia todo el Occidente. La obra de Knut Schäferdiek ${ }^{107}$ es un estudio clásico de la situación de la Iglesia en los reinos visigodo y suevo, y aunque está enfocada principalmente a las relaciones eclesiásticas con los poderes políticos, contiene un valioso análisis de las relaciones con Roma durante la regencia de Teodorico el Ostrogodo, pasando de la dependencia de Arlés a la relación directa con Roma, por vía precisamente de los vicariatos hispanos.

Aunque se aleja geográficamente del tema, no debe perderse de vista la relación entre el ocaso de los vicariatos de Arlés y Tesalónica y el ascenso político de los carolingios, por el posible paralelismo que puede establecerse con el caso

\footnotetext{
99 La cura pastoral...

100 «In alia plebe: cartas de comunión en las iglesias de la Antigüedad», en DELMAIRE, Roland, DESMULLIEZ, Janine, GATIER, Pierre-Louis (Eds.), Correspondances. Documents pour l'histoire de l'Antiquité tardive. Actes du colloque international, Lille, 20-22 novembre 2003, Lyon, 2009, pp. 83-113.

101 "Caesarius of Arles and the Lex Romana Visigothorum», en Studi in onore di Vincenzo ArangioRuiz nel XLV anno del suo insegnamento, Vol. I, Nápoles, 1953, pp. 201-217.

102 «Nueva luz sobre la España...»

103 «Els concilis eclesiàstics de la Tarraconensis durant el segle V», Annals de I'Institut d'Estudis Gironins, Vol. XXXVII, Gerona, 1996-97, pp. 1.041-1.057.

104 Chiesa e primato nelle lettere dei papi del secolo VII, Milán, 1971.

105 «La dottrina del Primato...»

106 JAMES, Edward, «Beati pacifici: Bishops and the Law in Sixth-Century Gaul», en BOSSY, J. (Ed.), Disputes and Settlements. Law and Human Relations in the West, Cambridge, 1983, pp. 25-46. Este autor hace referencia a las diferencias en todo lo referente a la cultura legal de ambos episcopados.

107 Die Kirche in den Reichen der Westgoten und Suewen bis zur Errichtung der westgotischen katholischen Staatskirche, Berlín, 1967, especialmente las pp. 68-81.
} 
hispano ${ }^{108}$. Friedrich Kempf y Josef A. Jungmann ${ }^{109}$ han presentado un estudio somero de los intentos postreros de consolidación o creación de nuevos vicariatos, y de la subordinación final de los mismos al poder civil.

\section{Vicariatos en Hispania}

Los vicariatos apostólicos hispanos podrían conformar un tema historiográfico en sí mismo, pero la realidad bibliográfica no parece corroborar esta impresión. Quizás hay que buscar una explicación en el hecho de que, entre el nombramiento de Zenón de Sevilla y el de Salustio, se produjo el final del Imperio Romano de Occidente y el comienzo de la creación de un Estado visigodo independiente, lo cual no sólo ha centrado la atención historiográfica, sino que tal cesura política funciona como un obstáculo para estudios de conjunto.

Lo primero que cabe señalar respecto a este tema es que los tres vicarios apostólicos de los que tenemos noticia que fueron nombrados en España han recibido una consideración de cierta excepcionalidad por parte de la historiografía, tanto nacional como extranjera ${ }^{110}$. El nombramiento de vicarios apostólicos, más allá de la forma en la que se acabarían desarrollando, supuso un punto de inflexión en las relaciones del Pontificado con las Iglesia hispanas y específicamente en el ejercicio efectivo del Primado, pasando de un modelo reactivo a otro en el que los Papas tomaron la iniciativa. El sucesor de Hilario en el Solio Pontificio, Simplicio (468-483), inauguró esta nueva forma de intervención papal en la Península. Para su mejor comprensión, un trabajo del Prof. Vilella ${ }^{111}$ explica la adaptación de la organización eclesiástica a las provincias civiles y la dependencia administrativa de las provincias de Hispania respecto de las Galias. García Moreno ${ }^{112}$ ha analizado la subordinación inicial de los obispos hispanos al vicariato de Arlés y su evolución posterior. Resultan especialmente interesantes los estudios que el mismo autor ha dedicado a las relaciones entre Roma y el Reino visigodo, incluyendo la tesis de una adaptación de la política papal a las nuevas realidades ad-

108 Sobre este asunto estoy trabajando con la Dra. Ana Arranz. La historiografía ha prestado atención a la relación entre la primacía de Toledo como manifestación de las relaciones Iglesia-Estado visigodo, y también como posible freno al poder de la Iglesia bizantina en Hispania, pero también cabe plantearse otras cuestiones, tales como si existe una relación entre el ascenso de Toledo y la desaparición de los vicariatos, o si, al nombrar al primado de Toledo con el título de legado apostólico, en tiempos ya de Gelmírez, no se está recuperando, mutatis mutandis, la idea del vicariato en España, i. e., lo que serán los legati nati.

109 «La jerarquía supradiocesana: metropolitas, primados y papas», en JEDIN, Hubert (Dir.), Historia de la Iglesia, Tomo III, Barcelona, 1980 (Friburgo, 1962), pp. 451-470.

110 Entre otros: MAROT, H., Opus Cit.; ORLANDIS ROVIRA, José, Historia de la Iglesia. I. La Iglesia Antigua y Medieval, Madrid, 1982 (1974); UBRIC RABANEDA, Purificación, La Iglesia en la Hispania del siglo V, Granada, 2004.

111 «Las primacías eclesiásticas...»

112 «La monarquía visigoda y la Iglesia en Levante. Las raíces de un país», Hispania Sacra, Vol. 49 (1997), pp. 253-277. 
ministrativas ${ }^{113}$. En su obra sobre el Primado, Madoz ${ }^{114}$ ha puesto el foco en el ámbito de lo eclesiástico, considerando los vicariatos en un contexto postcalcedoniano de defensa de la autoridad suprema de la Sede Apostólica sobre los demás obispos.

El primer vicario apostólico hispano del que tenemos noticia fue el obispo Zenón de Sevilla, quien obtuvo sus especiales prerrogativas del mencionado Papa Simplicio (468-483). La historiografía no suele cuestionar la procedencia hispalense de este vicario, con la excepción de J. Vives ${ }^{115}$, quien concluyó que se trataba del obispo de Mérida. Durante el papado de Hormisdas (514-523) fue nombrado vicario apostólico el obispo Salustio de Sevilla, surgiendo la controversia en torno a cuál era la posición de este nuevo vicario con respecto a Arlés ${ }^{116}$. Una cuestión algo distinta es la naturaleza del encargo del Papa Hormisdas al tercero de los vicarios apostólicos hispanos, el obispo Juan. Existe un dilatado debate historiográfico sobre un posible origen tarraconense o ilicitano de este obispo. La colección canónica Hispana lo presenta como obispo de Elche, aunque otros editores de grandes colecciones de fuentes, como Mansi, Migne o Jaffé, consideraron que el vicario fue Juan de Tarragona.

La mayor importancia relativa de la sede metropolitana de Tarragona ha llevado a considerar que el Papa elegiría a su obispo y no al de Elche como vicario. Como tal lo interpretan, entre otros, Rivera Recio ${ }^{117}$ y Ubric Rabaneda ${ }^{118}$. Por el contrario, consideran que se trata del obispo de Elche autores como Schäferdiek $^{119}$, Sotomayor ${ }^{120}$, Orlandis ${ }^{121}$, García Moreno ${ }^{122}$, Fernández Alonso ${ }^{123}$ y Federico-M. Beltrán Torreira ${ }^{124}$.

Las implicaciones de que se tratase de una u otra sede van más allá del detalle geográfico, al menos en cuatro direcciones que los autores antes mencionados han sopesado en mayor o menor medida: La presencia del vicariato de Arlés en la Galias y su influencia en las iglesias hispanas; el posible conflicto en la Bética; el conflicto en la Cartaginense; la naturaleza personalísima del nombramiento pontificio, que sobresaldría en caso de que el vicario fuera un obispo no metropolitano como el de Elche.

113 «Urbs cunctarum gentium victrix gothicis triumphs victa. Roma y el reino visigodo», en Roma fra Oriente e Occidente. XLIX Settimane di studio del Centro Italiano di Studi sull'Alto Medioevo. 19-24 aprile 2001, Spoleto, 2002, T. I, pp. 239-322; «La Iglesia en la España visigoda y postvisigoda: obispos y santos", en VV. AA., La Historia de la Iglesia en España y el Mundo Hispano, Murcia, 2001, pp. 91-120.

114 El Primado romano...

115 Inscripciones cristianas de la España romana y visigoda, Barcelona, 1969.

116 ORLANDIS, J., RAMOS-LISSÓN, D., Historia de los concilios...

117 «Encumbramiento de la Sede...»

118 La Iglesia en la Hispania....

119 Die Kirche in den Reichen...

120 La Iglesia en la España...

121 El Primado romano...

122 La monarquía visigoda...

123 La cura pastoral en la España...

124 «El conflicto por la primacía eclesiástica de la Cartaginense y el III Concilio de Toledo», en Concilio III de Toledo. XIV Centenario, 589-1989, Toledo, 1991, pp. 497-510. 
Además de la propia configuración territorial de esta naciente Hispania romano-visigoda ${ }^{125}$, los factores de política exterior añaden otras posibles interpretaciones, como la de Ramón de Abadal ${ }^{126}$ al considerar el control ostrogodo de la Tarraconense y la Cartaginense. Una línea historiográfica actual, en la que destacan Luis A. García Moreno ${ }^{127}$ y Margarita Vallejo Girvés ${ }^{128}$, ha interpretado que la concesión casi simultánea de vicariatos a Salustio de Sevilla y Juan de Elche podría reforzar la tesis de unas tierras béticas que lograron cierta independencia durante las primeras décadas del siglo VI.

En cuanto a la naturaleza de la institución del vicariato apostólico, Ángel C. Vega ${ }^{129}$ consideró que los vicarios apostólicos estaban en el mismo plano que los apocrisarios, y englobaba a ambas instituciones bajo el término de Delegados Apostólicos. Así pues, estaríamos ante una categoría específica de legados permanentes que, simplemente, serían enviados desde la propia nación, y no desde Roma ${ }^{130}$.

El camino hacia la primacía nacional del obispo de Toledo es paralelo a la desaparición de los vicarios apostólicos en Hispania, aunque sólo una parte de la historiografía suele considerar una relación de causalidad. Fernández Alonso ${ }^{131}$ sí ha relacionado ambas instituciones, y Beltrán Torreira ${ }^{132}$ ha interpretado el ascenso de los arzobispados (Cartagena y Toledo) como una amenaza directa a la primacía jurisdiccional de Roma. J. Rivera ${ }^{133}$ realizó un estudio de la consolidación del obispo de Toledo como metropolitano universal del episcopado hispanovisigodo, que sobrevivirá a la invasión musulmana. Al analizar este ascenso toledano es imprescindible considerar el imbricado sistema de relaciones Iglesia-Estado - por utilizar una terminología contemporánea- del Reino visigodo. Carlos de Ayala Martínez ${ }^{134}$ lo ha desarrollado con claridad y profundidad en una obra con interesantes aportaciones interpretativas históricas e historiográficas, así como una extensa bibliografía.

125 Para una adecuada comprensión de los cambios en la administración territorial civil y eclesiástica, que sin duda afectaron a la cuestión de los vicariatos: DÍAZ MARTÍNEZ, Pablo C., MARTÍNEZ MAZA, Celia, SANZ HUESMA, F. Javier, Hispania tardoantigua y visigoda, Madrid, 2007.

${ }^{126}$ Del Reino de Tolosa al Reino de Toledo, Madrid, 1960.

127 «Las invasiones y la época visigoda. Reinos y Condados cristianos», Romanismo y Germanismo. El despertar de los pueblo hispánicos (s. IV-X), en TUÑóN DE LARA, M. (Dir.), Historia de España II, Barcelona, 1981, pp. 243-505; «Los orígenes de la Carpetania visigoda», en Actas del Simposio Toledo y Carpetania en la Edad Antigua, Toledo, 1986 (1990), pp. 229-249.

${ }_{128}$ Bizancio y la España tardoantigua (ss. V-VIII): un capítulo de historia mediterránea, Alcalá de Henares, 1993.

129 «El Primado Romano en la Iglesia española...»

130 Aunque esta interpretación del P. Vega es interesante por sus implicaciones, consideramos preciso matizarla analizando todos los posibles aspectos comunes y divergentes entre ambas instituciones (vicarios apostólicos y legados), algo que hacemos en nuestra tesis, actualmente en proceso.

131 La cura pastoral..., pp. 234 y ss.

132 «El conflicto por la primacía eclesiástica...», pp. 497-510.

133 «Encumbramiento de la Sede toledana durante la dominación visigótica», Hispania Sacra, Vol. 8, Núm. 15 (1955), pp. 3-34.

134 Sacerdocio y Reino en la España Altomedieval, Madrid, 2008. 


\section{LAS RELACIONES A PARTIR DEL AÑO 526}

J. Orlandis ${ }^{135}$ ha estudiado los principales asuntos que en relación con el Primado romano tuvieron lugar durante la época visigoda. Asimismo, resulta útil para este periodo el recuento prosopográfico a partir de las fuentes realizado por García Moreno ${ }^{136}$, en el que recoge los principales personajes de la Hispania visigoda desde el reinado de Leovigildo hasta la invasión musulmana, en especial todos los obispos conocidos.

Es innegable que las relaciones entre Roma e Hispania se vieron afectadas desde el segundo tercio del s. VI por la muerte de Teodorico el Ostrogodo (526) y las subsiguientes Guerras Góticas, que devastaron el centro y sur de Italia, reduciendo los recursos del Pontificado al mínimo. Claudio Azzara ${ }^{137}$ analiza esta problemática situación del Papado en la Italia ostrogoda, desde Juan I hasta Vigilio, situación que para García Moreno ${ }^{138}$ implicó una Roma sometida a la política imperial bizantina.

Frente a una visión historiográfica que ha incidido en el sometimiento de los pontífices a las presiones de ostrogodos y de bizantinos, hay otra que identifica una acción pontificia cierta en el territorio peninsular más excéntrico, el Reino suevo, donde durante el mismo s. VI comenzó a desarrollarse una actividad sinodal con gran reconocimiento y estima hacia el magisterio de la sede romana ${ }^{139}$. Además de ello, se tiene noticia de una apelación a Roma realizada por el obispo metropolitano Profuturo de Braga ${ }^{140}$, quien, consternado por el rebrote del priscilianismo en su territorio, acudió al Papa pidiéndole consejo sobre cómo proceder desde el punto de vista pastoral con los distintos errores de la herejía. Fue respondido con una carta del Papa Vigilio en 538, que incluye toda una declaración del Primado de Roma y de las prerrogativas de la Sede Apostólica, en la línea de Sárdica sobre las apelaciones episcopales y causae maiores. En el Concilio I de Braga se procedió a la lectura y aceptación de la decretal del Papa Vigilio a Profuturo. Joaquim $\mathrm{O}$. Bragança ${ }^{141}$ ha realizado un estudio de dicha carta en el que no sólo corrobora las ideas generales de esta línea historiográfica en relación con la Sede romana, sino que considera que este documento fue la primera irradiación

135 «El Primado romano en la España visigoda», en Ídem, Estudios de Historia Eclesiástica visigoda, Pamplona, 1998 (publicado originalmente /l Primato del Vescovo di Roma nel primo millenio, Ciudad del Vaticano, 1991).

${ }_{136}$ Prosopografía del Reino visigodo de Toledo, Salamanca, 1974.

137 «ll Papato e il regno dei goti in Italia. Rapporti politico-diplomatici e costruzione della memoria storica», Nuova Rivista Storica, Núm. 94 (2010), pp. 89-104.

138 «Urbs cunctarum gentium...»

139 ORLANDIS, J., RAMOS-LISSÓN, D., Historia de los concilios...

140 Sobre Profuturo como primer metropolitano de Braga, vid. PRIETO VILAS, M., Los obispos hispanos..., pp. 130-134.

141 «A carta do Papa Vigílio ao Arcebispo Profuturo de Braga», en Actas do Congresso de Estudos da Comemoraçâo do XIII Centenário da morte de S. Fructuoso. Bracara Augusta, Vol. XXI, Núms. 47-50 (1967), pp. 65-91. 
de la liturgia papal, anticipándose en tres siglos a la unificación litúrgica que promovió Carlomagno.

Es cierto que no se conoce ninguna comunicación epistolar del Papado hacia el Reino visigodo de Toledo (Profuturo es obispo en el Reino de los suevos) hasta la época de Gregorio Magno. Como se verá en el siguiente apartado, este alejamiento entre Roma e Hispania, forzado en buena medida por el contexto político, dio lugar a una etapa de relaciones bien distintas a las que se han explicado hasta ahora.

Una cuestión que sí atañe a las relaciones del Reino visigodo con el Pontificado fue el postrer intento de Leovigildo de unificar el Estado en torno a una nueva fe arriana (según se recoge en el sínodo arriano de Toledo en 580), destacando el estudio que del mismo ha realizado $\mathrm{J}$. Orlandis ${ }^{142}$. Esta materia ha sido tratada generalmente por la historiografía desde el absorbente prisma del III Concilio de Toledo. Menos habitual es señalar, como ha hecho García Moreno ${ }^{143}$, que Leovigildo jugó una astuta baza galicana atacando al Papado por su connivencia con una potencia imperial herética (Tria Capitula) y extranjera como era Bizancio, y defendiendo con propaganda la nueva Iglesia visigoda surgida del sínodo de 580 como auténticamente católica, posición por cierto que se antoja pseudo-cismática. La obra colectiva publicada con motivo del XIV Centenario del famoso concilio ${ }^{144}$ contiene a su vez la bibliografía básica al respecto de la conversión de los visigodos arrianos al catolicismo y del III Concilio toledano.

\section{Gregorio Magno}

Con Gregorio I se inauguró una nueva manera de entender la sede pontificia, sus prerrogativas y sus relaciones con la autoridad secular. La bibliografía sobre Gregorio Magno es muy abundante y sobrepasa con mucho nuestro tema de estudio $^{145}$. No obstante, cabe señalar la dedicación que a este periodo y a este pontificado ha prestado la historiografía anglosajona, con las relevantes aportaciones de Robert A. Markus ${ }^{146}$. Fruto de esta línea de investigación es el estudio de David Hipshon ${ }^{147}$, que incide en lo novedoso del pensamiento político de este pontífice y en cómo concibe la cooperación entre la potestas civil y la auctoritas eclesiástica,

\footnotetext{
142 «El arrianismo visigodo tardío», Cuadernos de Historia de España, Núm. 65-66, Buenos Aires, 1981, pp. 5-20.

${ }_{143}$ «Disidencia religiosa y poder episcopal en la España Tardoantigua (ss. V-VII)», en LOMAS, Francisco Javier, DEVÍS, Federico (Eds.), De Constantino a Carlomagno. Disidentes, Heterodoxos, Marginados, Cádiz, 1992, pp. 135-158; «La coyuntura política del III Concilio de Toledo. Una historia larga y tortuosa", en Concilio III de Toledo. XIV Centenario, 589-1989, Toledo, 1991, pp. 271-296.

${ }_{144}$ Concilio III de Toledo. XIV Centenario, 589-1989, Toledo, 1991.

145 Una recopilación reciente en D'IMPERIO, Francesa Sara, Gregorio Magno: bibliografia per gli anni 1980-2003, Florencia, 2005.

${ }_{146}$ Gregory the Great and his world, Cambridge, 1997; From Augustine to Gregory the Great, Londres, 1983.

147 "Gregory the Great's Political Thought», Journal of Ecclesiastical History, Vol. 53, Núm. 3 (2002), pp. 439-453.
} 
ya sea por la vía martirial de Hermenegildo o por la de la conversión ejemplar de Recaredo. Revierte un interés especial el trabajo de Paul Magdalino ${ }^{148}$ sobre el sentido de la primacía y la supremacía de la Sede romana manifestado en el registro epistolar de Gregorio Magno, que el autor compara con el de Gregorio VII. Asimismo, son de gran utilidad, tanto para el estudio del pontificado de Gregorio I como para el asunto concreto que aquí se trata, las recientes traducciones y ediciones críticas de sus obras, tanto de su registro epistolar completo como de los Diálogos ${ }^{149}$.

Durante este pontificado se consolidó la institución del legado papal, pudiendo distinguirse cuatro categorías de enviados: evangelizadores, apocrisarios, administradores y legados en sentido estricto. Sin embargo, mientras la acción exterior del Papado no sólo se multiplicaba, sino que fructificaba, las relaciones con Roma de la Iglesia visigoda católica — después de la conversión de 589- han sido caracterizadas de forma recurrente por la historiografía con rasgos distintivos tales como una escasa comunicación, un mutuo desconocimiento, recelo, etc. A pesar de ello, no hay acuerdo sobre si se mantuvo el reconocimiento del Primado romano, una postura mantenida por autores como Madoz ${ }^{150}$ y Orlandis ${ }^{151}$. Esta misma conclusión es defendida por Teodoro González ${ }^{152}$ y Santiago Fernández Ardanaz ${ }^{153}$, quienes razonan que no sólo hubo testimonios de tal reconocimiento, sino ausencia documental de disensiones de orden doctrinal. Es importante señalar que otros historiadores, sin negar totalmente este argumento, matizan o contextualizan el reconocimiento de la primacía romana, identificando una tendencia al aislamiento o un particularismo de la Hispania visigoda del S. VII ${ }^{154}$.

Otra línea de investigación es la de C. Godoy y J. Vilella ${ }^{155}$, que consideran que las nuevas relaciones que desde 589 se establecieron entre el Estado visigo-

148 «Church, Empire an Christendom in c. 600 and c. 1075: The View from the Registers of Popes Gregory I and Gregory VII», en Cristianità d'Occidente e Cristianità d'Oriente (secoli VI-IX). LI Settimane di Studio del Centro Italiano di Studi sull'Alto Medioevo, Spoleto, 2004, Vol. I, pp. 1-30.

149 MARTYN, John R. C., The Letters of Gregory the Great, 3 Vols., Toronto, 2004; GALÁN, Pedro Juan, Vida de San Benito y otras historias de santos y demonios. Diálogos, Madrid, 2010.

150 «El Primado romano en España en el ciclo isidoriano», Revista Española de Teología, Vol. II/2, Madrid, 1942, pp. 229-255.

151 El Primado romano...

152 «Relaciones con Roma», en GARCÍA-VILLOSLADA, Ricardo, S.I. (Dir.), Historia de la Iglesia en España, Vol. I, Madrid, 1979, pp. 689-697.

153 «El pensamiento religioso en la época hispanovisigoda», en ANDRÉS, Melquíades (Dir.), Historia de la teología española. I. Desde sus orígenes hasta fines del siglo XVI, Madrid, 1983, pp. $257-356$.

154 GARCÍA VILLADA, Zacarías, «Organización y fisonomía de la Iglesia española desde 711 a 1085», Discurso de recepción en la RAH, Madrid, 1935 (Este autor insiste en el particularismo de la Iglesia hispana); TORRES, Manuel, España Visigoda, en MENÉNDEZ PIDAL, Ramón (Dir.), Historia de España, T. III, Madrid, 1940; MARAVALL, José Antonio, El concepto de España en la Edad Media, Madrid, 1981 (1954); GALLARDO, Paulino (Trad.), ANDRÉS, Melquiades (Introd.), Obras de San Gregorio Magno, Madrid, 1958; DÍAZ Y DÍAZ, M. C., «Introducción general», en OROZ RETA, J., MARCOS CASQUERO, M. A., Etimologías de San Isidoro de Sevilla, Madrid, 2009, pp. 7-257.

155 «De la fides Gothica a la ortodoxia nicena: inicio de la teología política visigoda», en Los visigodos. Historia y Civilización. Actas de la Semana Internacional de Estudios Visigodos, Antigüedad y Cristianismo, Núm. 3, Murcia, 1985, pp. 117-144. 
do y la Iglesia hispanovisigoda eran en sí mismas un impedimento para el reconocimiento de la primacía romana. El Prof. Vilella ${ }^{156}$ también ha realizado un análisis de las relaciones entre Gregorio I e Hispania, basado tanto en los registros epistolares como en los Diálogos, valorando específicamente las posiciones respectivas del Papado y del Reino visigodo frente al Imperio de Bizancio.

Además de un número de cartas — ciertamente exiguo en el conjunto de su inmensa herencia epistolar- Gregorio I buscó reforzar su primacía en Hispania mediante el envío de una serie de benedictiones con reliquias, una materia que ha sido estudiada de forma más amplia por J. M. McCulloh ${ }^{157}$, y sobre la que también ha trabajado Roger Collins ${ }^{158}$, señalando la especial valoración de dichas reliquias por parte de los monarcas visigodos.

En las relaciones de Roma con la Iglesia católica visigoda de tiempos de Recaredo destaca sin lugar a dudas la figura del obispo Leandro de Sevilla, amigo personal del Pontífice que actuó a modo de representante de la Iglesia hispana ante la Sede Apostólica. Leandro Navarra ${ }^{159}$ ha estudiado la relevancia del obispo hispalense en la historia política y eclesiástica de la Hispania del s. VI. La historiografía suele destacar la tibia relación entre Recaredo y Leandro de Sevilla ${ }^{160}$, la cual ha sido considerada por Santiago Castellanos ${ }^{161}$ como un posible motivo de la limitada comunicación entre el rey y el Papa.

Por otra parte, la concesión del pallium a Leandro por parte de Gregorio Magno fue un hecho excepcional en la historia de la Iglesia visigoda, como puede comprenderse al repasar la obra de John A. Eidenschink ${ }^{162}$ sobre el desarrollo histórico y la significación de este ornamento litúrgico, especialmente durante el pontificado de Gregorio I. La concesión del pallium a Leandro también puede entenderse como una continuidad del vicariato apostólico de Sevilla (Zenón-SalustioLeandro), o al menos una intención de tal continuidad, y así es como parece inter-

156 «Gregorio Magno e Hispania», en Gregorio Magno e il suo tempo. XIX Incontro di studiosi dell'antichità cristiana, Studia Ephemeridis Augustinianum, Núm. 33, Roma, 1991, pp. 167-186.

157 «The Cult of Relics in the Letters and 'Dialogues' of Pope Gregory the Great: a lexicographical Study», Traditio, Núm. 32 (1976), pp. 145-184.

158 "Continuity and Loss in Medieval Spanish Culture: the Evidence of MS Silos, Archivo Monástico 4", en COLLINS, R., GOOGMAN, A. (Eds.), Medieval Spain. Culture, Conflict, and Coexistence. Studies in Honour of Angus MacKay, Hampshire, 2002.

159 «Interventi di Leandro di Siviglia negli sviluppi storici e religiosi della Spagna visigotica: aspetti positivi e limiti», Studi Storico Religiosi, Núm. IV/1 (1980), pp. 123-134.

160 Resulta interesante la aproximación a las relaciones entre el rey y el prelado hispalense a partir del estudio de los textos latinos de las Actas del III Concilio toledano, en MELLADO RODRíGUEZ, Joaquín, «Leandro y Gregorio Magno: ¿Sólo lecciones de humildad para la soberbia de Recaredo?», en PÉREZ GONZÁLEZ, Maurilio (Coord.), Actas. III Congreso Hispánico de Latín Medieval (León, 26-29 de Septiembre de 2002), Vol. II, León, 2002, pp. 803-812.

161 Los godos y la cruz. Recaredo y la unidad de Spania, Madrid, 2007.

162 The election of bishops in the letters of Gregory the Great with an Appendix to the pallium, Washington, D.C., 1945, pp. 101-143. Asimismo es interesante un resumen con las principales hipótesis de la historiografía alrededor de los orígenes del pallium, en Miscellany, «The pallium», Catholic Historical Review, Núm. 8/1 (1922), pp. 64-71. 
pretarlo el Prof. García Moreno ${ }^{163}$. En todo caso, la cuestión del pallium y su relación con una posible condición de vicario apostólico de su receptor son inseparables de la reflexión sobre el Primado romano y su reconocimiento en Hispania, como queda reflejado en las obras de Conte ${ }^{164}$, Maccarrone ${ }^{165}$ o Vilella ${ }^{166}$.

Una hipótesis que explicaría la discontinuidad vicarial durante varias décadas es la inestabilidad provocada por la invasión bizantina de España, especialmente en Hispalis, a lo que habría que sumar una cierta tendencia independentista en esa misma zona. Aunque sin relacionarlos directamente con la cuestión del vicariato, estos argumentos fueron planteados por J. Orlandis ${ }^{167}$, y más recientemente han sido estudiados en profundidad por la Prof. Vallejo Girvés ${ }^{168}$.

\section{Las relaciones del Papado con la provincia bizantina de Spania}

Algo más fluida que con la Iglesia del Reino visigodo fue la comunicación entre el Papa y la Iglesia de la provincia bizantina en Hispania. De nuevo hemos de remitirnos a la espinosa cuestión de la presencia bizantina en España como factor mutuo de limitación de las relaciones entre Roma y la Iglesia hispanovisigoda. Además de las obras anteriormente señaladas, cabe destacar otros trabajos de Amancio Isla Frez ${ }^{169}$, Francisco Presedo Velo ${ }^{170}$ y M. Vallejo Girvés ${ }^{171}$.

Por ello no ha de sorprender que la principal comunicación entre el Papa Gregorio I y la Península tuviera como destinataria a la provincia imperial hispana. En primer lugar tenemos noticia de la carta de sincera preocupación del obispo Liciniano de Cartagena por el difícil cumplimiento de la Regula Pastoralis gregoriana; estudiada junto con el resto de su registro epistolar por Madoz ${ }^{172}$, la carta es una muestra de que el magisterio de Roma tuvo importante predicamento en la Hispania bizantina.

Mucho más directa fue la intervención de Gregorio I en el caso del magister militum Spaniae Comitiolus y la deposición irregular de los obispos lanuarius y

163 «Urbs cunctarum gentium...»

164 Chiesa e primato nelle lettere dei papi...

165 «La dottrina del Primato...»

166 «Hispania durante la época del III Concilio de Toledo según Gregorio Magno», en Concilio III de Toledo. XIV Centenario, 589-1989, Toledo, 1991, pp. 485-494.

167 «Gregorio Magno y la España visigodo-bizantina», en CARLÉ, M. C., GRASSOTTI, H., ORDUNA, G. (Eds.), Estudios en homenaje a Don Claudio Sánchez Albornoz en sus 90 años, Buenos Aires, 1983 pp. 329-348.

168 Bizancio y la España tardoantigua...; Hispania y Bizancio. Una relación desconocida, Madrid, 2012.

169 «Los reinos bárbaros y el Papado entre los siglos VI y VII», en De la Antigüedad al Medievo. Siglos IV-VIII. III Congreso de Estudios Medievales, Fundación Sánchez-Albornoz, Madrid, 1993, pp. 65-94.

170 La España bizantina, Sevilla, 2003. Esta obra póstuma recoge el grueso de la Tesis Doctoral inédita del Prof. Presedo.

171 «Las relaciones políticas entre la España visigoda y Bizancio», en CORTÉS ARRESE, Miguel (Coord.), Toledo y Bizancio, Cuenca, 2002, pp. 75-112.

172 Liciniano de Cartagena y sus cartas. Edición crítica y estudio histórico, Madrid, 1948. 
Esteban, un tema que ha sido específicamente estudiado por F. J. Presedo ${ }^{173}$ y M. Vallejo ${ }^{174}$. La autenticidad de las capitulares, cuestionada en su momento por Flórez, ha sido bien argumentada por la misma Prof. Vallejo Girvés ${ }^{175}$. Tenemos noticia del envío a Málaga de un primer legado papal, el presbítero Probinus, que tuvo como encargo la cuestión de Comitiolus y que también informó a Gregorio de la situación general del Reino visigodo tras la conversión, tal como ha estudiado J. Vilella ${ }^{176}$.

El asunto no se resolvió con la actuación de Probinus ${ }^{177}$, ya que unos años después el Papa envió como legado al defensor Juan, y esta vez Gregorio I le dotó de unas atribuciones extraordinarias para el cumplimiento de su misión. Beltrán Torreira ${ }^{178}$ relaciona la legación del defensor Juan con un intento de limitar la voluntad expansiva de la Cartagena imperial y con el auge definitivo de la primacía hispana de Toledo. La figura de los defensores y su encaje en la administración pontificia gregoriana ha sido someramente estudiada por Jeffrey Richards en su gran obra sobre Gregorio Magno ${ }^{179}$, y también ha sido analizada desde el punto de vista del Derecho romano, como una evolución específica del defensor plebis y conjuntamente con la figura del notario, ambas utilizadas prolijamente por el Papa Gregorio ${ }^{180}$. A diferencia de los notarios, varios de los defensores son mencionados en el corpus documental gregoriano como subdiáconos, y este carácter de ordenados los situaría en una posición muy específica si tenemos en cuenta el carácter monástico que Gregorio Magno imprimió a la corte pontificia. Fernández Ardanaz ${ }^{181}$ ha tratado sobre la compleja evolución histórica del subdiaconado, desde el enfoque del ámbito hispánico. Acerca de la organización burocrática y la administración territorial y jurisdiccional de tiempos del Papa Gregorio I es impor-

173 En La España bizantina, Presedo analiza exhaustivamente las posibilidades de identificación histórica del personaje Comitiolus. Asimismo se estudia la vigencia del Derecho bizantino en la Península a través de la actuación del defensor Juan.

174 «Bizancio ante la conversión de los visigodos: Los obispos Jenaro y Esteban», en Concilio III de Toledo. XIV Centenario, 589-1989, Toledo, 1991, pp. 477-483.

175 VALLEJO GIRVÉS, Margarita, «Enrique Flórez y sus contemporáneos ante la intervención de Gregorio Magno en obispados de la España bizantina», Hispania Sacra, Núm. 49 (1997), pp. 655-673.

176 Relaciones exteriores de la Península Ibérica durante la Baja Romanidad (300-711): prosopografía, Barcelona 1987, pp. 402-404; «Hispania durante la época del III Concilio...».

177 Probinus tampoco llegó a entrevistarse con el rey Recaredo, como estaba previsto. La actitud de Bizancio hacia la población hispana parece que se endureció tras la conversión de 589, como demostraría la petición de Recaredo al Papa de una copia de los tratados con Justiniano y la propia misión del defensor Juan de 603. WOOD, Jamie, «Defending Byzantine Spain: frontiers and diplomacy», Early Medieval Europe, Núm. 18 (2010), pp. 292-319.

178 «El conflicto por la primacía eclesiástica...», pp. 497-510.

179 Consul of God. The life and Times of Gregory the Great, Londres, 1980.

180 GONZÁLEZ FERNÁNDEZ, Rafael, «Las cartas de Gregorio Magno al defensor Juan. La aplicación de Derecho de Justiniano en la Hispania bizantina en el siglo VII», Antigüedad y Cristianismo, Vol. 14, Murcia, 1997, pp. 287-298; MARTYN, J. R. C., Opus Cit., «Introduction», Vol. 1.

181 «El pensamiento religioso en la época...». De forma más sucinta el asunto aparece tratado en SÁNCHEZ SALOR, Eustaquio, Jerarquías eclesiásticas y monacales en época visigótica, Salamanca, 1976. 
tante el estudio de Ch. Pietri ${ }^{182}$, pero quizás es Victor Saxer ${ }^{183}$ quien ha realizado el trabajo más completo sobre el origen y la evolución altomedieval de la organización de la administración pontificia.

El defensor Juan llegó a Hispania en el año 603. El asunto principal que debía resolver era el ya mencionado de Comitiolus, pero previamente acudió a la pequeña isla de Cabrera (en Baleares) con el encargo pontificio de reformar la disciplina de los monjes. Da idea de la amplitud del encargo legatino, así como de la buena información que el Papa poseía de aquellas tierras imperiales, de acuerdo con el estudio realizado por J. Orlandis ${ }^{184}$.

\section{EL SIGLO VII DESPUÉS DE GREGORIO MAGNO}

Tras el pontificado de Gregorio Magno y hasta la invasión musulmana, apenas tenemos noticia de dos asuntos que provocaron comunicaciones directas entre Roma y la Iglesia visigoda. En los Regesta de Jaffé se recogen seis cartas pontificias válidas que tratan asuntos hispanos, frente a las veintisiete sobre la Francia merovingia y las cuarenta del ámbito anglosajón. Aunque considerásemos que otras cartas se hubieran perdido, la comparación seguiría arrojando un balance muy pobre. José M. Lacarra ${ }^{185}$ así lo interpreta en su trabajo sobre las relaciones de la Iglesia hispana con la Sede romana en el S. VII. Todos los asuntos que definen dichas relaciones han sido recogidos por García Moreno ${ }^{186}$ en un estudio del conjunto de las relaciones diplomáticas de la monarquía visigoda.

Admitiendo la realidad histórica de una escasez de relaciones con Roma de este siglo VII, García Villada ${ }^{187}$ la justificó por la distancia y la inseguridad de la navegación provocada por la piratería vándala. Madoz ${ }^{188}$ considera un conjunto más amplio de causas externas e internas que explicarían la referida situación; destacando entre las externas la presencia bizantina en el mediterráneo y en Italia

182 «Clercs et serviteurs laics de l'Église romaine au temps de Grégoire le Grand», en FONTAINE, Jacques, GILLET, Robert, PELLISTRANDI, Stan (Eds.), Grégoire le Grand. Actes des Colloques internationaux du Centre National de la Recherche Scientifique, Chantilly 1982, París, 1986, pp. $107-122$.

183 «La Chiesa di Roma dal V al X secolo: Amministrazione centrale e organizzazione territoriale», en Roma nell'Alto Medioevo. XLVIII Settimane di Studio del Centro Italiano di Studi sull'Alto Medioevo, Spoleto, 2001, Vol. II, pp. 493-632 (para el tema que nos ocupa interesan especialmente las pp. 523-528).

184 «Problemas en torno a la cristiandad balear en la época preislámica», Anuario de Historia de la Iglesia, Núm. 8 (1999), pp. 145-157.

185 «La Iglesia visigoda en el siglo VII y sus relaciones con Roma», en Le Chiese nei regni dell'Europa occidentale e i loro rapporti con Roma sino all'800. VII Settimane di Studio del Centro Italiano di Studi sull'Alto Medioevo, Spoleto, 1959, pp. 353-384.

186 «Relaciones internacionales del reino godo de Toledo en el siglo VII: de la faida gótica a la obsesión bizantina», en Le relazioni internazionali nell'Alto Medioevo. LVIII Settimane di Studio del Centro Italiano di Studi sull'Alto Medioevo, Spoleto, 2011, pp. 481-557.

187 Opus Cit., T.II/1.

188 MADOZ, J., «El Primado romano en España en el ciclo...». Vid. asimismo las obras anteriormente señaladas sobre la primacía de Toledo. 
como un factor específicamente negativo para la Hispania visigoda; en cuanto a las causas internas que limitarían la comunicación con Roma, la principal fue el propio florecimiento de la Iglesia visigoda, fuertemente jerarquizada en torno a Toledo. En directa relación con este argumento, otra causa interna para el relativo aislamiento sería la intrínseca unión que se produjo entre la Iglesia visigoda y el poder regio visigodo tras la conversión de 589. Salvando la discusión historiográfica mantenida por parte de algunos historiadores del Derecho sobre la naturaleza de los concilios toledanos, la historiografía viene coincidiendo desde hace décadas (Madoz, Orlandis, Ayala, etc.) en esta visión de imbricación político-religiosa del Reino visigodo de Toledo. Más concretamente, J. Orlandis ${ }^{189}$ ha señalado el importante papel político que jugaron los altos cargos eclesiásticos godos desde la unificación de 589, y la mediatización que sufrieron sus nombramientos por parte de la monarquía, especialmente en la segunda mitad del s. VII.

Al escaso balance de relaciones con Roma para un periodo de más de 100 años, hay que añadir el hecho de que los dos casos de comunicación que conocemos fueron incidentes que enfrentaron al Papado con una parte del episcopado hispano. En primer lugar, el Papa Honorio I envió en 638 una carta con duros reproches al episcopado hispánico por su postura negligente hacia los judíos. En los trabajos de Sandalio Aznar Tello ${ }^{190}$ y Paloma Ortiz García ${ }^{191}$ se analiza la influencia de San Braulio en la vida eclesial y cultural de su tiempo. Aunque no era metropolitano, intervino en los concilios IV, $\mathrm{V}$ y VI de Toledo ${ }^{192}$, y era una figura de reconocida talla intelectual en el clero, como discípulo de San Isidoro, pero también como consejero al que acudieron tanto los reyes como los principales protagonistas del renacimiento cultural hispanogodo del s. VII. De ahí que en el VI Concilio (638) los prelados le eligieran para dar respuesta al Papa Honorio I en nombre del episcopado hispano.

Tal como han señalado, entre otros, Lacarra y Fernández Ardanaz, es el de San Braulio un texto escrito en un tono firme para quejarse de la solicitud del Papa, que consideraba innecesaria, pues creía que las acusaciones se debían a rumores infundados. En este sentido, Raúl González Salinero ${ }^{193}$ ha analizado la posible relación entre las exhaustivas medidas contra los judíos del VI Concilio toledano y la intervención del Papa Honorio I. La carta de San Braulio ha de contextualizarse en el conjunto de su obra, que ha sido estudiada por C. H. Lynch y P. Galindo ${ }^{194}$; en lo referente específicamente al epistolario, los trabajos de referencia

189 «El elemento germánico en la Iglesia española del siglo VII», Anuario de Estudios Medievales, Núm. 3 (1966), pp. 27-64. Concluye Orlandis que hubo un claro decaimiento de la calidad episcopal. Es razonable considerar que esta interferencia política en la jerarquía hispana episcopal (no tanto monástica), acentuada tras el papel otorgado al primado toledano en el XII Concilio, afectara también a su posición hacia la Iglesia universal y, específicamente, hacia la Sede Apostólica.

190 San Braulio y su tiempo. El fulgor de una época, Zaragoza, 1986.

191 «San Braulio, la Vida de San Millán y la Hispania Visigoda del siglo VII», Hispania Sacra, Vol. 45, Núm. 92 (1993), pp. 459-486.

192 VIVES, J. (Ed.), Concilios visigóticos...

193 Las conversiones forzosas de los judíos en el reino visigodo, Roma, 2000.

194 San Braulio. Obispo de Zaragoza (631-651). Su vida y sus obras, Madrid, 1950. 
son las ediciones críticas en latín y en castellano realizadas respectivamente por José Madoz ${ }^{195}$ y Luis Riesco Terrero ${ }^{196}$.

A partir de los hechos y de las fuentes mencionadas, se han venido desarrollando unas interpretaciones historiográficas radicalmente divergentes. García Moreno ${ }^{197}$ considera que la respuesta del obispo de Zaragoza fue una declaración de autonomía jurisdiccional de la Iglesia visigoda frente a las pretensiones del Primado romano. Sin embargo, otros autores entienden que existe en el propio texto de San Braulio un reconocimiento indudable del Primado romano en la Iglesia universal. De esta manera lo ha interpretado García Villada, así como los mencionados Lynch y Galindo, Riesco Terrero y Aznar Tello. J. Madoz ${ }^{198}$ reconoce el tono de acritud del obispo de Zaragoza, pero lo interpreta como una prueba de su amargura al sentir que se había cuestionado injustamente la perfecta ortodoxia de la Iglesia visigoda. El hecho mismo de este intercambio epistolar dentro de un ambiente jurídico se considera como señal de unas relaciones ciertas entre Roma y España. Rastreando otras posibles huellas de la posición de Braulio frente a Roma, cabe señalar una carta escrita a su hermano Frunimiano, en la que Braulio mostraba su conocimiento e interés sobre las costumbres de la Iglesia romana, como recoge un trabajo de Vicenç Janeras ${ }^{199}$ en relación con ciertas cuestiones litúrgicas.

El segundo caso de comunicación -y de controversia- de la Iglesia hispanogoda con el Papado tuvo como detonante los llamados Apologéticos de Julián de Toledo. Rivera Recio ${ }^{200}$ ha realizado una contextualización histórica y una semblanza del que fuera el primero de los primados de la Iglesia hispana y su época. El conflicto se produjo cuando el Papa León II instó, por medio de su notario regionario Pedro, al episcopado hispano a suscribir la condena del monotelismo decretada en el III Concilio de Constantinopla. La petición era relativamente normal y no debería haber provocado ninguna crisis. Tal como ha señalado Madoz ${ }^{201}$, León II expresó sin ambages la doctrina de la primacía de base petrina.

El hecho en sí de las desavenencias, el que el Papa dirigiese la carta a Quírico de Toledo, fallecido tres años atrás, el que ningún obispo hispano fuera invitado al III Concilio constantinopolitano, así como la proverbial ausencia de otros registros, son varios de los factores que han llevado a la mayor parte de los historiado-

195 Epistolario de S. Braulio de Zaragoza, Madrid, 1941; el mismo autor publicó poco tiempo después un exhaustivo trabajo de crítica hermenéutica sobre el epistolario de San Braulio: «Autenticidad de las cartas de San Braulio de Zaragoza», Estudios eclesiásticos, Vol. 17, Núm. 67 (1943), pp. 433-486.

196 Epistolario de San Braulio. Introducción, edición crítica y traducción, Sevilla, 1975. Esta obra contiene un extenso análisis filológico latino, aunque la crítica histórica es más extensa en la edición de Madoz.

197 «Urbs cunctarum...»

198 «El Primado romano en España en el ciclo...»

199 «Dos pasajes de san Braulio de Zaragoza sobre aclamaciones litúrgicas», Hispania Sacra, Vol. 18, Núm. 36 (1965), pp. 243-247.

200 San Julián, arzobispo de Toledo (s. VII). Época y personalidad, Barcelona, 1944.

201 «San Julián de Toledo», Estudios Eclesiásticos, Vol. 26, Núm. 100 (1952), pp. 39-69. 
res a insistir en una incomunicación de la Iglesia hispana con Roma durante varias décadas ${ }^{202}$.

Los estudios realizados desde finales del siglo XIX, y de manera especial los llevados a cabo desde el ámbito protestante, han calificado de nacional a la Iglesia de la Hispania visigoda, pero no tanto para recalcar la estrecha relación existente entre Iglesia y Estado sino más bien para transmitir la idea de una situación pseudocismática de la Iglesia hispanovisigoda. Un ejemplo es la obra de Franz Görres ${ }^{203}$, cuya conclusión subraya la existencia de un ultraje al Papa por parte de Julián de Toledo y un rechazo total de Roma. También ciertos historiadores católicos ${ }^{204}$ han insistido en la existencia de un camino hacia el cisma emprendido por Julián de Toledo, cisma que se habría completado de no ser por la irrupción musulmana.

En tiempos más recientes encontramos varias interpretaciones en la misma línea sobre este episodio, aunque con distintos matices: como una reacción de cariz galicanista (García Moreno), de resentimiento frente a las pretensiones de la primacía petrina (Lacarra), o bien directamente de cesaropapismo por parte de la monarquía visigoda (King). Todo ello conduciría en la práctica a una mayor independencia de la Iglesia hispana respecto de la Sede romana. María R. Valverde Castro $^{205}$ ofrece un enfoque diferente, analizando la situación creada por el arzobispo toledano como un reflejo más de la imitatio imperii desarrollada desde tiempos de Recaredo. En la misma línea se ha manifestado J. N. Hillgarth ${ }^{206}$, quien además interpreta los episodios de Braulio de Zaragoza y de Julián de Toledo como muestras de la frágil unidad del Estado visigodo.

En su estudio sobre los llamados síntomas españoles, Abilio Barbero ${ }^{207}$ ha rastreado un origen africano de la doctrina teológica visigoda, especialmente en lo referido a dos cuestiones: la doble procedencia o Filioque, con un largo recorrido y aceptación en Roma, y la de las tres sustancias, que enfrentó a Julián de Toledo con el Papa y, posteriormente, con los teólogos carolingios en tiempos del adopcionismo. De nuevo el fantasma del africanismo de la Iglesia española sería causa de alejamiento de Roma.

La controvertida personalidad del arzobispo Julián de Toledo ha sido abundantemente señalada por la historiografía, en especial por quienes niegan categóricamente que la Iglesia hispana cuestionase el Primado romano durante la segunda

202 LACARRA, J. M., Opus Cit.; KING, P. D., Law and Society in the Visigothic Kingdom, Cambridge, 1972; ORLANDIS, J., «El Primado romano en la España visigoda»...; GARCÍA MORENO, L. A., «Urbs cunctarum...».

203 «Der Primas Julián von Toledo (680-690). Eine Kirchen-Kultur und litterargeschichtliche Studie», Zeitschrift für wissenschaftliche Theologie, Núm. XLVI (1903), pp. 538-553.

204 GAMS, Pío Bonifacio, Die Kirchengeschichte von Spanien, Vol. II/2, Regensburg, 1874.

205 Ideología, simbolismo y ejercicio del poder real en la monarquía visigoda, Salamanca, 2000.

206 «Historiography in Visigothic Spain», en La storiografia altomedievale. XVII Settimane di Studio del Centro Italiano di Studi sull'Alto Medioevo, Spoleto, 1970, Vol. I, pp. 261-311.

207 «Los síntomas españoles y la política religiosa...» 
mitad del s. VII. Estos autores ${ }^{208}$ suelen argumentar separando el contenido del segundo Apologeticus de su tono de «tensión teológica», lo cual presenta notables paralelismos con algunas de las interpretaciones ofrecidas para el caso de San Braulio de Zaragoza. Asimismo, las manifestaciones de romanismo en la Iglesia hispanovisigoda, como la celebración de la fiesta in cathedra Sancti Petri y la continua referencia a las decretales como fuente de derecho, se aducen como gestos de reconocimiento del Primado, al menos en cuanto a la autoridad doctrinal (Lynch y Galindo, Madoz). En su estudio prosopográfico de los arzobispos toledanos anteriores y posteriores a Julián, Rivera Recio ${ }^{209}$ concluye que el asunto de los Apologéticos sólo resaltó la fama teológica de Julián de Toledo, tanto en Roma como en Constantinopla.

Frente a la interpretación rupturista fundamentada en un programa político del Estado visigodo de tipo galicanista o cesaropapista, otros autores interpretan que los hispanovisigodos desarrollaron un sistema político-eclesiástico de mutua necesidad basado en un equilibrio - no siempre logrado- entre el pactismo episcopal y el autoritarismo regio. Carlos De Ayala ${ }^{210}$ es probablemente quien mejor argumenta esta idea, que también ha sido planteada por Santiago Fernández Ardanaz $^{211}$, Manuel Díaz y Díaz ${ }^{212}$ o Santiago Castellanos ${ }^{213}$. Valverde Castro ${ }^{214}$ ha ofrecido un enfoque distinto pero complementario de las relaciones de poder en el Reino visigodo de Toledo, distinguiendo una acción legitimadora del poder real por parte de la Iglesia institucional, pero al mismo tiempo un enfrentamiento a los monarcas en el ámbito de lo socioeconómico.

Francis X. Murphy ${ }^{215}$ planteó un análisis que ponderaba las limitaciones de las fragmentarias fuentes disponibles para el asunto de los Apologéticos, estudiando el caso como parte de un contexto más amplio del episcopado de Julián de Toledo, sobre todo en relación con su posible participación, junto con Ervigio, en la deposición del rey Wamba.

\footnotetext{
${ }^{208}$ Además de autores ya citados como García Villada, Torres, Lynch y Galindo, Madoz o Rivera, Vid. MAGNIN, Etienne, «Rome et l'Eglise wisigothique», en Ídem, L'Église wisigothique au VIIe siècle, París, 1912, pp. 3-31.

209 «Los arzobispos de Toledo en el siglo VII», en Anales Toledanos. III. Estudios sobre la España visigoda, Toledo, 1971, pp. 181-218.

210 Sacerdocio y Reino..., Capítulo 1, en especial pp. 19-38.

211 «El pensamiento religioso en la época...», pp. 257-356.

212 «Los discursos del rey Recaredo: El Tomus», en Concilio III de Toledo. XIV Centenario, 589-1989, Toledo, 1991, pp. 223-248.

213 "Obispos y santos. La construcción de la Historia cósmica en la Historia visigoda», en AURELL, Martín, GARCÍA DE LA BORBOLLA, Ángeles (Eds.), La imagen del obispo hispano en la Edad Media, Pamplona, 2004, pp. 15-36.

214 «La Iglesia hispano-visigoda: ¿Fortalecedora o limitadora de la soberanía real?», Historia Antiqua, Núm. 16 (1992), pp. 381-392.

215 «Julian of Toledo and the Fall of the Visigothic Kingdom in Spain», Speculum, Vol. 27, Núm. 1 (1952), pp. 1-27.
} 
Orlandis ${ }^{216}$ introduce un elemento que refuerza la impresión de un cierto alejamiento efectivo respecto del Primado papal: en el s. VII tenemos noticia de al menos dos causae maiores en la Iglesia hispana que no fueron ni sometidas ni apeladas a la autoridad suprema del Papa. En primer lugar, la deposición del obispo Marciano de Écija, solventada en un concilio del que no conservamos las actas, muy probablemente celebrado en Sevilla, y cuya apelación se hizo ante el IV Concilio de Toledo y no ante Roma. En segundo lugar, la deposición del primado Sisberto de Toledo, que fue ratificada por el XVI Concilio de Toledo (693), aduciendo la inviolabilidad de los reyes como ungidos del Señor. La unción regia dio a la Iglesia hispana un gran poder en cuanto elemento constitutivo de la monarquía, pero dificultaba cualquier intervención de la Sede Apostólica. Abilio Barbero ${ }^{217}$ ha estudiado la historia de la unción real visigoda, y Carlos De Ayala ${ }^{218}$ ofrece una aproximación a la materia con bibliografía relevante.

Desconocimiento, desconfianza, controversia e incluso riesgo de cisma son algunas de las notas con las que buena parte de los historiadores han caracterizado las relaciones entre el Papado y la Iglesia hispana en el s. VII. No obstante, pueden añadirse dos elementos de contrapunto a esta visión, que quizás llevarían a rebajar el hipotético nivel de incomunicación, y menos aún de enfrentamiento, existente. En primer lugar, el respeto a la autoridad pontificia entre los tratadistas y juristas hispanos del momento, que se manifestó expresamente en distintos momentos en las actas conciliares, así como en la recepción en la colección canonística hispana de las decretales y de los cánones universales ${ }^{219}$. El segundo elemento es el viaje que realizó Tajón de Zaragoza a Roma con el encargo ${ }^{220}$ del rey Chindasvinto de conseguir aquella parte de los Moralia in lob de Gregorio Magno que no tenían disponibles en España. Apareció recogido por vez primera en la Crónica Mozárabe de 754, y la narración es una de las de mayor riqueza informativa de toda la obra, lo cual tiene que ver con las fuentes del propio autor anónimo, como ha estudiado José Eduardo López Ferreira ${ }^{221}$.

\footnotetext{
216 «Tras la huella de un concilio isidoriano de Sevilla», Anuario de Historia de la Iglesia, Núm. 4 (1995), pp. 237-246.

217 «El origen visigodo de la unción real», en La sociedad visigoda y su entorno histórico, Madrid, 1992, pp. 56-77; «Los síntomas españoles y la política religiosa...»

218 Sacerdocio y Reino..., pp. 47-49.

${ }^{219}$ MAGNIN, Etienne, «Rapports du droit canon espagnol avec celui de l'Eglise universelle», en Ídem, L'Église wisigothique au VIIe siècle, París, 1912, pp. 32-46; VIVES, J. (Ed.), Concilios visigóticos e hispano-romanos...; MARTíNEZ DÍEZ, Gonzalo, S.I., La colección canónica hispana. I. Estudio, Madrid, 1966.

${ }^{220}$ Esta es la misión principal de acuerdo con la narración de la Crónica de 754.

${ }_{221}$ Crónica mozárabe de 754. Edición crítica y traducción, Zaragoza, 1991 (1980); Estudio crítico sobre la Crónica mozárabe de 754, Zaragoza, 1980. En estas dos obras el autor presenta una edición crítica y una traducción de la Crónica. El texto latino con un estudio de las fuentes en GIL, Juan (Ed.), Corpus scriptorum muzarabicorum, Madrid, 1973, T. I.
} 
El viaje ha sido estudiado por J. Madoz ${ }^{222}$ y especialmente por García More${ }^{n}{ }^{223}$, quien concluye que tuvo casi con seguridad un carácter político, en el contexto del conflicto entre el Papado y el emperador bizantino Constante II, relacionándolo además con las embajadas del rey visigodo a África. Sea como fuere, este episodio nos informaría de que existieron ciertas relaciones con la Sede romana en la segunda mitad del s. VII. Pero además, Tajón fue amigo, discípulo doctrinal y sucesor en la sede episcopal de Zaragoza de San Braulio, protagonista como se ha visto de un supuesto enfrentamiento con Roma.

La ausencia de fuentes directas no es óbice para tratar de identificar otros testimonios. ¿Estaba realmente tan aislada la Iglesia hispanovisigoda del s. VII? El estudio de las relaciones con Bizancio arroja resultados interesantes: la posible "desconfianza» visigoda en cuestiones teológicas respecto a Roma no se debería al desconocimiento ni al avance de posturas de tipo galicanista, sino a la relación entre el Papado y Bizancio. Como señalan Antonio Bravo García ${ }^{224}$ y L. A. García Moreno ${ }^{225}$, esta relación era fruto de la necesidad para el Papado, pero se hizo cada vez más estrecha, lo cual debió de generar una importante tensión en la Hispania visigoda, en especial con la política de restauración bizantina en Occidente llevada a cabo por parte de Constante II.

Por otra parte, una línea de estudio ha interpretado que la imitatio imperii del Reino visigodo lo orientó culturalmente hacia Bizancio ${ }^{226}$, mientras que a partir del análisis de las principales manifestaciones literarias en la Hispania del s. VII ${ }^{227}$, la conclusión puede ser bien distinta, destacando la influencia de San Agustín, de Isidoro de Sevilla y, lo que más incumbe a la cuestión del Primado, de Gregorio Magno, cuya obra es citada o seguida (regula pastoralis) por los hispanovisigodos ${ }^{228}$.

Un último elemento para tratar de ponderar adecuadamente el nivel de aislamiento de la Iglesia visigoda es su contextualización en el conjunto de la actividad diplomática internacional, la cual, como ha estudiado Paul S. Barnwell ${ }^{229}$, languidecía en el s. VII. Aún más, François Bougard ${ }^{230}$ considera que el papel jugado por el Papado en las relaciones internacionales de esta época fue débil.

222 «Tajón de Zaragoza y su viaje a Roma», en Mélanges J. De Ghellinck, Gembloux, 1951, pp. 345-360.

223 «Relaciones internacionales del reino godo...»; «Urbs cunctarum...».

224 «La España visigoda y el mundo bizantino», en CORTÉS ARRESE, Miguel (Coord.), Toledo y Bizancio, Cuenca, 2002, pp. 123-165.

225 «Relaciones internacionales del reino godo...»

226 HILLGARTH, J. N., «Historiography in Visigothic Spain»...

227 DÍAZ Y DÍAZ, Manuel, «La cultura de la España visigótica del siglo VII», en Caratteri del secolo VII in Occidente. V Settimane di Studio del Centro Italiano di Studi sull'Alto Medioevo, Spoleto, 1958, Vol. II, pp. 813-844.

228 SERRANO, L., «La obra Morales de San Gregorio en la literatura hispanogoda», Revista de Archivos, Bibliotecas y Museos, Núm. 24 (1911), pp. $482-497$.

229 «War and peace: historiography and seventh-century embassies», Early Medieval Europe, Vol. 6, Núm. 2 (1997), pp. 127-139.

230 «Petitor et medius: Le rôle de la Papauté dans les relations internationales de Grégoire le Grand à Jean VIII», en Le relazioni internazionali nell'Alto Medioevo. LVIII Settimane di Studio del Centro Italiano di Studi sull'Alto Medioevo, Spoleto, 2011, pp. 299-341. Concluye Bougard que el papel del Papado 


\section{EL PRIMADO ROMANO EN ESPAÑA DESPUÉS DEL AÑO 711}

La invasión musulmana interrumpió para siempre el desarrollo político del Reino de Toledo y también la transmisión de las fuentes. Se baraja la hipótesis de la celebración de un postrer Concilio toledano, no recogido en la colección canónica, que habría refrendado los cánones del concilio Quinisexto. Las cuestiones sobre moralidad de dicho controvertido concilio parecen presentes en el Toledano XVI (693), aunque sin referencias expresas a aquél, y fueron utilizadas por la primera cronística tras la conquista musulmana como una prueba de la inmoralidad que asolaba el Reino de Toledo ${ }^{231}$. No hay documentos coetáneos del Reino visigodo después de 702, pero a mediados del s. VIII retornan las fuentes de carácter historiográfico, que han sido recogidas en un estudio de M. Díaz y Díaz ${ }^{232}$.

En la Crónica de 754 no encontramos referencias expresas a relaciones entre la Iglesia mozárabe y la Santa Sede desde la conquista musulmana de 711. Ahora bien, sí se menciona que el diácono Pedro, de la sede de Toledo, escribió un libeIlum a los sevillanos fijando la fecha de la Pascua (año 750) ${ }^{233}$. Es un detalle indirecto el que la cuestión de la Pascua fuera un asunto de interés en la España mozárabe, puesto que era una materia de extraordinario interés para Roma. Tres décadas más tarde, Adriano I insistió prolijamente en este asunto en dos de sus cartas a los obispos hispanos. La crónica mozárabe también nos narra el triste episodio del arzobispo toledano Sinderedo, exiliado, notoriamente, en la ciudad de Roma bajo el amparo del Papado ${ }^{234}$.

\subsection{Iglesia mozárabe e Iglesia franca. La reacción adopcionista}

A finales del s. VIII se produjeron en España dos problemas teológicos consecutivos y relacionados entre sí: el primero, las estrambóticas explicaciones trinitarias de Migencio, contestadas duramente por Elipando de Toledo; el segundo, de mucho mayor alcance, la herejía adopcionista defendida por el mismo arzobispo toledano. En cuanto a la cuestión de Migencio, sabemos que hubo una legación a España a este respecto, y que estuvo encabezada por el obispo Egila. Se ha lle-

en las relaciones internacionales (ss. VII-IX) fue escaso, aunque se fuera consolidando como "sujeto internacional» por derecho propio.

${ }^{231}$ GARCÍA MORENO, L. A., "Relaciones internacionales del reino godo...». Si efectivamente la normativa del Quinisexto se hubiese trasladado a la colección canónica hispana, se trataría de una nueva manifestación del respeto de la Iglesia española a las decisiones emanadas del Pontificado, especialmente cuando se considera lo controvertido de la normativa conciliar ecuménica en cuanto a moral eclesiástica.

232 "La historiografía hispana desde la invasión árabe hasta el año 1000», en La storiografia altomedievale. XVII Settimane di Studio del Centro Italiano di Studi sull'Alto Medioevo, Spoleto, 1970, Vol. I, pp. 313-343.

${ }^{233}$ LÓPEZ FERREIRA, J. E., Crónica mozárabe...

${ }^{234}$ GARCÍA MORENO, L. A., «Urbs cunctarum...." 
gado a entender que el Papa otorgó la sede episcopal de Elvira a dicho Egila ${ }^{235}$ y de hecho no parece una legación papal al uso, puesto que, además, la iniciativa de la misma partió del arzobispo Wilcario, primado de la Iglesia franca y, en última instancia, del propio rey Carlomagno. No obstante, en el contexto del renaciente Imperio carolingio no era tan extraña la participación directa del rey Carlos en las cuestiones de la Iglesia.

Las relaciones entre la Iglesia hispana y la Sede romana en el s. VIII estuvieron especialmente marcadas por el asunto del adopcionismo. Los principales temas tratados por la historiografía han sido los referidos a la valoración del carácter heterodoxo de los textos de Elipando y de Félix de Urgel, a las relaciones entre la Iglesia mozárabe y las demás iglesias cristianas peninsulares, a la penetración de la Iglesia franca en el norte hispano, así como a la intencionalidad política de la actuación de los carolingios. José Antonio y Amalia Riestra ${ }^{236}$ han realizado un repaso exhaustivo de la bibliografía histórico-teológica, que contiene las principales publicaciones hasta el año 1994. Cabe señalar también algunas obras que se salen del marco cronológico de la anterior recopilación ${ }^{237}$, destacando especialmente el trabajo de García Moreno ${ }^{238}$, ya que interpreta que hubo una negación por parte de la jerarquía de la Iglesia mozárabe de la primacía romana, al menos en su vertiente doctrinal. No es ésta la conclusión de un estudio de Rivera Recio $^{239}$ que relaciona el adopcionismo con la cuestión de la liturgia mozárabe, caballo de batalla de la futura reforma gregoriana. Por su parte, Barbero ${ }^{240}$ incide más en la idea de una Iglesia nacional hispana contraria a las pretensiones uniformadoras de Carlomagno.

Los reinados de Alhakam I, Abderramán II y, sobre todo, Muhammad I, resultaron de especial presión, tanto fiscal como social, para la Iglesia mozárabe y para todos los cristianos en territorio andalusí. Ello se manifiesta de forma paradigmática en el control ejercido por los emires sobre la Iglesia hispana (concilios, nombramientos episcopales), recogido tanto por las fuentes musulmanas como por las obras de San Eulogio ${ }^{241}$. Pero incluso en tiempos tan difíciles para las iglesias mozárabes se observan huellas de una relación nunca interrumpida del todo con

235 ALDANA GARCÍA, María Jesús, Obras completas de San Eulogio: introducción, traducción y notas, Córdoba, 1998.

236 «Bibliografía sobre el adopcionismo español del siglo VIII: 1951-1990», Scripta Theologica, Núm. 26/3 (1994), pp. 1.093-1.152, en especial el listado de las pp. 1.095-1.122.

${ }^{237}$ MENÉNDEZ PELAYO, M., Historia de los heterodoxos, T. I; DE ABADAL Y DE VINYALS, Ramón, La batalla del Adopcionismo en la desintegración de la Iglesia visigoda. Discurso en la recepción en la Real Academia de Buenas Letras de Barcelona, Barcelona, 1949.

238 «La Iglesia en la España visigoda y postvisigoda...»

239 «La controversia adopcionista del siglo VIII y la ortodoxia de la liturgia mozárabe», Ephemerides Liturgicae, Núm. 47 (1933), pp. 506-536.

240 «Los síntomas españoles y la política religiosa...»

241 IBN HAYYAN, Crónica de los emires Alhakam I y Abdarramán II entre los años 796 y 847 [A/muqtabis II-1], ALÍ MAKKÍ, Mahmud, CORRIENTE, Federico (Trads. y Eds.), Zaragoza, 2001; ALDANA GARCÍA, M. J., Opus cit.; PÉREZ DE URBEL, Justo, O.S.B., San Eulogio de Córdoba o la vida andaluza en el siglo IX, Madrid, 1942 (1927). 
Roma, como es el caso de los herejes casianistas (839), quienes argumentaban ser enviados de Roma para resaltar con ello su autoridad doctrinal, con lo que Roma siguió siendo una referencia cierta entre los mozárabes ${ }^{242}$.

El s. IX es el del resurgir del Papado tras la crisis del Imperio carolingio. En el caso hispano, el patriarcado único de Roma sobre el Occidente no se cuestionó, toda vez que la invasión musulmana se llevó por delante las pretensiones autonomistas tanto de un potencial primado regional africano en Cartago, como de uno hispano en Toledo ${ }^{243}$.

\subsection{Otros asuntos en relación con el Primado romano en España}

Tanto en la crónica de Ambrosio Morales como en la colección Sáenz de Aguirre se narra el envío del Papa Juan VIII (872-882) ante el rey Alfonso III el Magno y el arzobispo Sisenando de Iria del legado Reynaldo ${ }^{244}$. Hasta tiempos recientes no se dudaba de la autenticidad de este episodio ni de las cartas que el monarca y el pontífice se cruzaron ${ }^{245}$. Sin embargo, autores contemporáneos como José Luis Martín ${ }^{246}$ han considerado las cartas como una total falsificación llevada a cabo por el autor de la Crónica de Sampiro.

El estudio crítico de la Crónica de Sampiro de Justo Pérez de Urbel ${ }^{247}$ y trabajos específicos más recientes ${ }^{248}$ insisten en la dificultad para diferenciar aquella parte de la crónica que fue del propio Sampiro, de las partes añadidas por el obispo Pelayo y por el compilador silense en el s. XII; aunque consideran que el texto de la legación fue intercalado por el obispo Pelayo de Oviedo, señalan que algunos de los añadidos de Pelayo habrían venido a corregir acertadamente las versiones anteriores. Estas cartas serían señal de comunicación notablemente estrecha con Roma, así como de una autoridad jurisdiccional plena del Primado romano, que habría transformado en metropolitana la sede compostelana.

242 GIL, Juan (Ed.), Corpus Scriptorum Mozarabicorum, T. I, Madrid, 1973; SIMONET, Francisco Javier, Historia de los mozárabes de España, T. II, Madrid, 1983 (1897-1903).

243 KEMPF, F., Chiese territoriali e chiesa romana...

244 Puesto que la Historia Compostelana es la fuente que ambos mencionan, es útil la notable edición crítica de la misma en FALQUE REY, Emma, Historia Compostelana, Madrid, 1994.

245 CARVALLO, Luis Alfonso, S. I., Antigüedades y cosas memorables del Principado de Asturias, Parte II, Madrid, 1695 (1613); YEPES, Antonio, O.S.B., Corónica General de la Orden de San Benito, T. IV, Valladolid, 1613; RISCO, Manuel, O.S.B., España Sagrada, T. XXXVII y XXXVIII, Madrid, 1872.

246 «Orígenes de las Órdenes Militares. La Orden de Santiago», en IZQUIERDO BENITO, Ricardo, RUIZ GÓMEZ, Francisco (Coords.), Alarcos, 1195: Actas del Congreso Internacional conmemorativo del VIII centenario de la Batalla de Alarcos, Ciudad Real, 1996, pp. 31-45.

247 Sampiro. Su crónica y la monarquía leonesa en el siglo X, Madrid, 1952.

248 ALONSO ÁLVAREZ, Raquel, «La obra histórica del obispo Pelayo de Oviedo (1089-1153) y su relación con la Historia legionensis (Ilamada silensis)», e-Spania, 14 diciembre 2012 [10/05/2013], disponible en http://e-spania.revues.org/21586. 
Josep Amengual ${ }^{249}$ y José Orlandis ${ }^{250}$ han estudiado la intervención del Papado en relación con los pretendidos derechos de la iglesia de Gerona sobre las islas de Mallorca y Menorca. Se trató de un ejercicio de la primacía jurisdiccional pontificia, registrada documentalmente en sendas bulas de los papas Formoso (892) y Romano (897) que fueron dirigidas al obispo Servusdei de Gerona, como respuesta a los sucesivos viajes del prelado gerundense a la Ciudad Eterna.

Un último caso, del que no hay unanimidad por parte de los historiadores ni en cuanto a su realidad histórica ni en cuanto a la fecha en que habría tenido lugar, es el de la legación del presbítero Zanello, enviado a Hispania por el Papa Juan. El texto latino que narra esta legación puede hallarse en Flórez (T. III) y una traducción completa del mismo en Ambrosio de Morales (T. VI), a partir del Codex Aemilianensis. El problema radica en la datación de los hechos a partir de la mención de cuatro personajes en la crónica: un Papa Juan, un obispo Sisenando de Iria, un rey Carlos de Francia y un rey Ordoño de León. La tesis de Flórez parece ser la más plausible, fechando la legación en 918, como confirmarían los Annales de Baronius (T. XV). Por otra parte, Manuel R. García Álvarez ${ }^{251}$ o Demetrio Mansilla ${ }^{252}$, entre otros, han abordado la cuestión de la historicidad de la legación de Zanello. El Cronicón Iriense considera a Zanello como un enviado del obispo Sisnando al Papa, es decir, que no se trataría de un legado pontificio. Sea como fuere, y tal como ha señalado A. Isla Frez ${ }^{253}$, se está reforzando la idea de la ortodoxia romana de la sede compostelana y sus estrechas relaciones con el Pontificado.

El Papado del s. X no sólo sufrió de corrupción, nepotismo e inmoralidad, sino también de una paulatina desaparición en la práctica de toda iniciativa relacionada con las ideas de universalismo y de primacía jurisdiccional y doctrinal que habían sido desarrolladas conceptualmente desde los primeros tiempos del Pontificado, y puestas en acción - con mayor o menor éxito- por buena parte de los Papas hasta entonces. El s. XI, en lo que a las manifestaciones del Primado romano en España se refiere, tuvo como materia de referencia el cambio litúrgico, y como protagonistas a los monjes cluniacenses, pero ambas cuestiones formaban parte de un proyecto mucho más ambicioso por su amplitud, como fue el de la reforma gregoriana. Desde la llamada prerreforma hubo una figura institucional que cobró un protagonismo creciente en la acción exterior del Papado, protagonismo que ya

${ }^{249}$ Els origens del Cristianisme a les Balears $i$ el seu desenvolupament fins de l'època musulmana, Vol. II, Mallorca, 1992.

250 "Problemas en torno a la cristiandad balear en la época preislámica», Anuario de Historia de la Iglesia, Núm. 8 (1999), pp. 145-157.

251 «El Cronicón Iriense. Estudio preliminar, edición crítica y notas históricas», Memorial Histórico Español, Núm. L (1963), pp. 1-240.

${ }^{252}$ La curia romana y el reino de Castilla, Burgos, 1944.

253 «Ensayo de historiografía medieval. El Cronicón Iriense», En la España Medieval, Vol. 4 (1984), pp. 413-431. 
no perdió hasta tiempos muy recientes: el legado pontificio. Esta institución legatina medieval está siendo objeto de nuestro actual estudio, esta vez no sólo historiográfico sino histórico, que esperamos que pronto vea la luz.

\section{CONCLUSIONES}

Es un hecho abundantemente señalado por la historiografía que las fuentes para el periodo estudiado, salvo excepciones como el registro documental de Gregorio Magno, son escasas y casi siempre fragmentarias. Podría considerarse, a priori, que la mayor o menor abundancia de fuentes en cada caso sería proporcional al volumen generado de historiografía. Esta correlación positiva parece cumplirse para algunas épocas y temas, como el período del s. VIII anterior a la cuestión adopcionista en cuanto a la escasez de bibliografía, o el del pontificado de Gregorio Magno en cuanto a la abundancia, pero en otros casos se verifica lo contrario, como queda patente en el caso de San Cipriano y la deposición de Basílides y Marcial. Se observa que algunos de los asuntos específicos relacionados con la primacía romana en España revierten notablemente más interés que otros, y ello parece estar relacionado con el objeto más amplio de los estudios en que se incluyen. Así, la época de los visigodos, en especial el proceso de su establecimiento en la península y su desarrollo político-cultural del s. VII, sería, en general, el período más estudiado.

En cuanto a la cuestión en sí del Primado romano, unas pocas obras de conjunto fueron realizadas a comienzos del $\mathrm{s}$. XX, y la producción historiográfica recibió un nuevo impulso a raíz de la celebración del Vaticano II. Por el contrario, con posterioridad a las obras deudoras del último concilio ecuménico, encontramos una cierta falta de interés historiográfico por la cuestión. Apenas hay trabajos de conjunto, y menos aún para el caso específico de la Península ibérica. Como ha podido observarse, en numerosas ocasiones el repaso historiográfico ha tenido que ampliarse a obras no específicamente referidas a las relaciones con Roma y el Primado, por contener interpretaciones parciales al respecto, o bien arrojar luz para comprender la situación del Primado romano en el ámbito hispánico.

Aunque el periodo considerado transcurre, en buena medida, tanto histórica como historiográficamente a caballo entre la historia Antigua y la Medieval (ss. V-VII), son los historiadores de la Antigüedad quienes en tiempos recientes han prestado mayor atención a esta época de profundos cambios sociales, tanto individualmente como en proyectos de investigación, revistas y congresos. Valgan como ejemplo las obras mencionadas de L. A. García Moreno y de J. Vilella Masana. Creemos que sería bueno para la historiografía que los medievalistas se sumaran con renovado interés a este campo de investigación, pues si bien mirando hacia el mundo antiguo encontramos una lógica interpretativa de este periodo de transición, la mirada sobre lo que surgió puede ayudar a completar la 
imagen. Las estructuras sociales y las mentalidades no sólo cambiaron irremisiblemente a medida que el Imperio desaparecía, sino que los cambios perduraron, configurando lo que hemos denominado «Medievo». Esta consideración es válida también cuando analizamos la historia de la Iglesia, y especialmente la acción del Pontificado, como ha podido observarse en las páginas anteriores. La evolución de la institución del Pontificado no corresponde a la que en términos políticos experimenta el Occidente con la llegada de los reinos bárbaros. Por supuesto que es fruto de condicionamientos políticos como el desmoronamiento de la pars occidentalis y el establecimiento de las nuevas monarquías germánicas, pero sus cesuras no son las mismas que en la historia política. El Primado romano se fortalece con León I, mientras el poder militar de Roma se resquebraja; se renueva con Gregorio Magno, a pesar de Bizancio y los lombardos; y reacciona de nuevo con el ocaso de los carolingios.

La historiografía del último medio siglo utiliza las herramientas metodológicas que hoy se consideran adecuadas, acudiendo a la filología, la arqueología, la diplomática, y cualesquiera ciencias auxiliares de la historia que le son requeridas. Pero en lo que al estudio del Primado romano se refiere, quizás adolezca de una visión de conjunto ${ }^{254}$ : observamos un desarrollo teórico y una manifestación práctica de la primacía romana en las relaciones exteriores del Papado que, en el caso hispano, hunde sus raíces en la más temprana historia de su Iglesia, y que tiene una larga duración hasta el nuevo modelo reformista del siglo XI. Por ello cobra especial sentido el estudio conjunto, y por ello las relaciones con Roma no deben estudiarse sólo como relaciones diplomáticas, sino que configuran un modelo en el que han de incluirse los vicariatos apostólicos, el arzobispado, el pallium, las manifestaciones en la canonística y en la liturgia, la expansión del culto a los santos, el auge de Toledo como sede primada nacional y las legaciones pontificias más tempranas.

Cabe señalar cómo, en buena parte de los asuntos que se han tratado, las conclusiones de unos investigadores y otros pueden llegar a ser diametralmente opuestas en lo que al papel del Primado romano se refiere. Esta realidad se ha podido constatar en temas como: la participación de San Cipriano en el asunto de la deposición de Basílides y Marcial, la valoración de la apelación de Prisciliano a Roma, la naturaleza y poder jurisdiccional de los vicariatos apostólicos, la explicación de la escasez de comunicaciones con Roma en el s. VII, los asuntos de San Braulio de Zaragoza y San Julián de Toledo y la cuestión del adopcionismo.

El tema de la primacía ha suscitado y suscita ciertas «pasiones» historiográficas. En ocasiones se aprecian visiones algo finalistas, especialmente las prove-

254 TEJA, Ramón, «Una mirada a los estudios sobre el cristianismo antiguo en España», en SANTOS, Juan, TEJA, Ramón (Eds.), Revisiones de Historia Antigua III. El cristianismo. Aspectos históricos de su origen y difusión en Hispania. Actas del Symposium de Vitoria-Gasteiz (25 al 27 de noviembre de 1996), Vitoria, 2000, p. 31. 
nientes de la historiografía eclesiástica protestante con respecto a una imagen preconcebida de Iglesia contrarreformista. En otros casos, la negación casi sistemática de la acción del Primado en España es una constante, y no sólo entre los historiadores no religiosos, sino también en buena parte de la historiografía católica, tanto eclesiástica como laica, quizás motivada por una concepción de corte galicanista de la Iglesia española. Asimismo, se ha señalado cómo la idea de excepcionalidad de la historia de España vuelve a sobrevolar una vez más ciertas interpretaciones, como sucede con el nombramiento de los vicarios apostólicos hispanos. 
